\title{
Sleep Disturbances as a Risk Factor for Stroke
}

\author{
Dae Lim Koo, ${ }^{\mathrm{a}}$ Hyunwoo Nam, ${ }^{\mathrm{a}}$ Robert J. Thomas, ${ }^{\mathrm{b}}$ Chang-Ho Yun ${ }^{\mathrm{c}}$
}

\begin{abstract}
aDepartment of Neurology, Seoul Metropolitan Government Seoul National University Boramae Medical Center, Seoul National University College of Medicine, Seoul, Korea

${ }^{b}$ Division of Pulmonary, Critical Care and Sleep Medicine, Department of Medicine, Beth Israel Deaconess Medical Center, Boston, MA, USA 'Department of Neurology, Bundang Clinical Neuroscience Institute, Seoul National University Bundang Hospital, Seoul National University College of Medicine, Seongnam, Korea
\end{abstract}

\begin{abstract}
Sleep, a vital process of human being, is carefully orchestrated by the brain and consists of cyclic transitions between rapid eye movement (REM) and non-REM (NREM) sleep. Autonomic tranquility during NREM sleep is characterized by vagal dominance and stable breathing, providing an opportunity for the cardiovascular-neural axis to restore homeostasis, in response to use, distress or fatigue inflicted during wakefulness. Abrupt irregular swings in sympathovagal balance during REM sleep act as phasic loads on the resting cardiovascular system. Any causes of sleep curtailment or fragmentation such as sleep restriction, sleep apnea, insomnia, periodic limb movements during sleep, and shift work, not only impair cardiovascular restoration but also impose a stress on the cardiovascular system. Sleep disturbances have been reported to play a role in the development of stroke and other cardiovascular disorders. This review aims to provide updated information on the role of abnormal sleep in the development of stroke, to discuss the implications of recent research findings, and to help both stroke clinicians and researchers understand the importance of identification and management of sleep pathology for stroke prevention and care.
\end{abstract}

Keywords: Sleep initiation and maintenance disorders; Sleep; Sleep apnea syndromes; Stroke; Cardiovascular system; Homeostasis

\author{
Correspondence: Chang-Ho Yun \\ Department of Neurology, Seoul \\ National University Bundang Hospital, \\ Seoul National University College of \\ Medicine, 82 Gumi-ro 173beon-gil, \\ Bundang-gu, Seongnam 13620, Korea \\ Tel: +82-31-787-7469 \\ Fax: +82-31-787-4059 \\ E-mail:ych333@gmail.com \\ Received: December 13, 2017 \\ Revised: January 7, 2018 \\ Accepted: January 15, 2018
}

\section{Introduction}

Stroke incidence and early stroke mortality have been decreasing, at least in developed countries, although stroke remains one of leading causes of death and significant disability worldwide. ${ }^{1-5}$ Identification and active modification of risk factors, as well as progress in acute stroke care, underlie the improvements in stroke statistics. Modifiable risk factors such as high blood pressure, hyperlipidemia, diabetes, smoking, physical inactivity, and unhealthy diet are responsible for $90 \%$ of the risk of stroke. ${ }^{6,7}$ However stroke incidence has not dropped significantly in young adults, and is still soaring in low and middle income countries. ${ }^{2,3,8}$ The absolute numbers of stroke victims and resulting deaths, and the associated societal burden are great and even increasing. ${ }^{2}$ Insufficient modification of the established risk factors, or the ongoing effects of under-recognized risks, might explain the high global burden of stroke. Recently, the role of sleep pathology in the development of cardiovascular and metabolic diseases has been highlighted by experimental and observational studies. ${ }^{9-15}$ 
Sleep is an indispensable part of life, as with feeding and reproduction, all animal species require sleep. Humans sleep almost one-thirds of their lifetime, which is similar in industrialized and in pre-industrial societies. ${ }^{16,17}$ Sleep, although characterized by quiescence and diminished responsiveness, is not a simple state of rest, but rather a cyclic state of periodic transitions between rapid-eye-movement (REM) and non-REM (NREM) sleep, which are precisely regulated by the central nervous system. ${ }^{18}$ Along with the brain and other organs or physiological streams, the cardiovascular system achieves homeostatic restoration during sleep, mainly through autonomic circulatory control. ${ }^{19}$ For example, the decrease in blood pressure during sleep, "dipping," is a key biomarker of cardiovascular health, secondary to changes in activity and posture and also under the influence of sleep and circadian rhythms. ${ }^{20,21}$ During NREM sleep, the largest portion (up to $80 \%$ ) of normal adult sleep, the autonomic system is stabilized with vagal dominance, reduced sympathetic tone, and heightened baroreceptor gain, contributing to a significant reduction in blood pressure and heart rate, with the greatest drop occurring during slow wave sleep. ${ }^{21-24}$ This salutatory milieu makes it easy for the cardiovascular system to maintain homeostasis. In contrast, REM sleep-occupying about 20\% of total sleep-is dominated by marked fluctuations in sympathovagal balance (irregularly peaking sympathetic surges against a background of tonic vagal inhibition), which lead to abrupt changes in blood pressure and heart rate., 99,22,24 $\mathrm{A}$ compromised cardiovascular system is at risk for pathological events such as myocardial ischemia or arrhythmias during REM sleep. Sleep thus acts as a gatekeeper through cyclic oscillations between NREM and REM sleep, switching between autonomic tranquility and turmoil.

Any causes of sleep curtailment, including sleep restriction, insomnia, and shift work, are likely to impair cardiovascular restoration through a reduction in cardioprotective stable NREM sleep. Sleep fragmentation, conventionally defined by cortical EEG arousals, is a universal feature of almost all sleep disorders, including sleep apnea, insomnia, periodic limb movements during sleep (PLMS) and narcolepsy, and is associated with overshoots in sympathetic activity. ${ }^{25,26}$ Even if REM sleep is preserved, the greater the sleep fragmentation, the farther the sympathovagal modulation is tilted toward sympathetic dominance. ${ }^{27}$ Blood pressure regulation during the biological night (the usual sleep time) is uniquely related to cardiovascular risk, including the risk of stroke. ${ }^{28-30}$ Non-dipping-loss of the typical blood pressure drop during sleep-is associated with a host of poor cardiac, neurological, metabolic, and renal outcomes. ${ }^{31-36}$ Sleep fragmentation causes non-dipping. ${ }^{37-40}$ Nondipping is common in older adults and is associated with an increased risk of stroke. ${ }^{41-43}$ Reduced dipping is associated with brain atrophy, worse functional status, and lower daytime cerebral blood flow. ${ }^{44,45}$

The deleterious effects of sleep disturbances go far beyond autonomic circulatory derangement. Common sleep disorders such as sleep apnea, insomnia, and PLMS activate multiple mechanisms including intermittent hypoxia-reoxygenation injury, inflammation, insulin resistance, hypothalamic-pituitaryadrenal axis activation, hemodynamic swings, cardiac arrhythmia, and hypercoagulability, all of which have the potential to provoke cardiovascular diseases (Figure 1).9,46

However, compared with studies on well-established risk factors, research on the role of sleep pathology in the development of cardiovascular diseases, including stroke, has largely been observational or experimental..$^{13,47-58}$ To complicate matters, recent randomized trials have failed to determine the beneficial effect of positive airway pressure therapy in the secondary prevention of cardiovascular events or mortality in sleep apnea. ${ }^{59-61}$ However, serious flaws are pervasive in these studies, including poor use of therapy. This review aims to (1) provide an update of the available information regarding the role of sleep disturbances on the development of stroke; (2) discuss the implications of recent clinical trials and observational studies; and (3) help both stroke clinicians and researchers understand the importance of identification and management of sleep pathology for primary prevention in the general and stroke-prone populations, and for the care of acute and chronic stroke.

\section{Obstructive sleep apnea}

Obstructive sleep apnea (OSA) is characterized by repetitive cessations or reductions in airflow caused by complete or partial upper airway collapse (Figure 2). The prevalence of moderate-to-severe OSA in the adult general population is $9 \%$ to $14 \%$ in men and $4 \%$ to $7 \%$ in women, ${ }^{62-65}$ increasing with age $^{66}$ and even higher in a recent study (49.7\% in men, $23.4 \%$ in women) ${ }^{67}$ Measurement methods and scoring criteria heavily impact reported prevalence rates. Nevertheless, the prevalence and incidence of OSA is clearly increasing, driven by the aging of societies and the obesity epidemic. ${ }^{68}$ Four decades after a report on the high prevalence of hypertension in pediatric and adult $\mathrm{OSA}_{1}{ }^{69}$ numerous experimental and observational studies have provided evidence that OSA promotes the development of cardiovascular diseases, including stroke., 9,12,46,70

\section{Links between OSA and stroke}

OSA creates a substrate for stroke vulnerability, and is particu- 


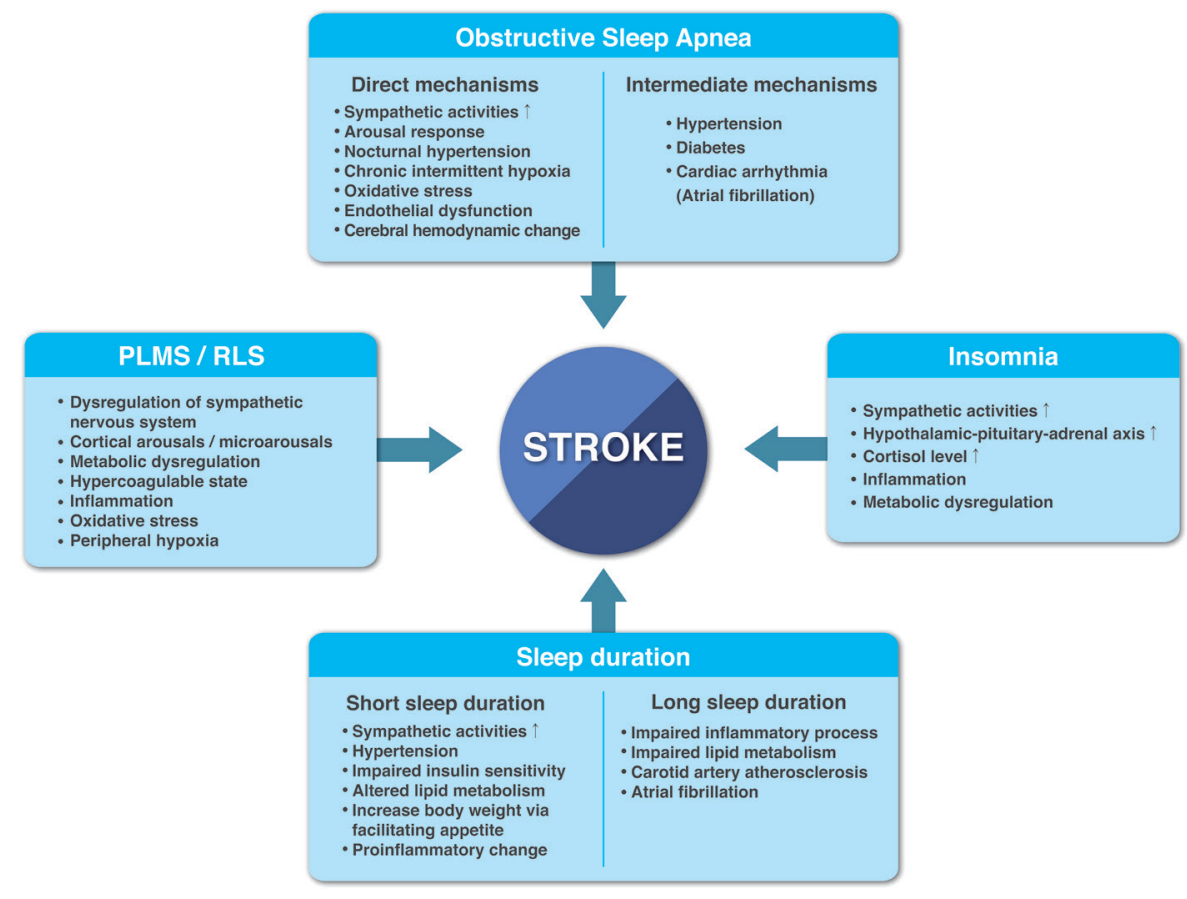

Figure 1. The mechanisms of sleep disturbances contributing to the development of stroke. PLMS, periodic limb movements during sleep; $\mathrm{RLS}$, restless legs syndrome.

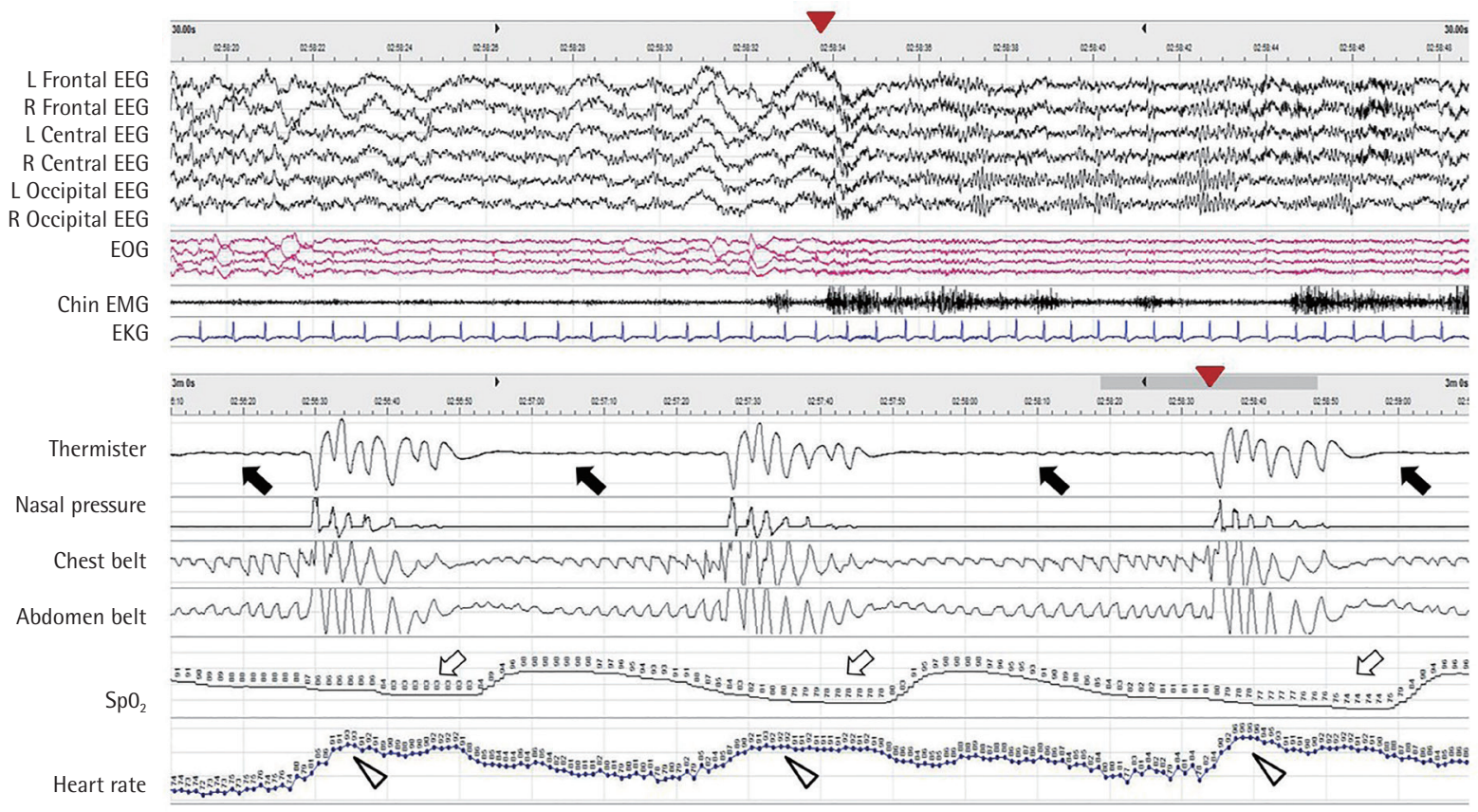

Figure 2. Snapshot of recurrent respiratory events in obstructive sleep apnea. (A) Electroencephalography (EEG) plots for 30-second epoch. Respiratory arousal (closed arrowhead in panel A) occurs at the end of obstructive sleep apnea (closed arrowhead in panel B) in stage 2 rapid-eye-movement (REM) and non-REM sleep. The closed arrowheads on panel A and B indicate the same time. (B) Respiratory plots for three-minute epoch. Repetitive cessations of airflow (closed arrows) despite ongoing respiratory movements of the chest and abdominal belt are typical features. Obstructive sleep apnea is accompanied by decreased oxygen saturation (open arrows) and increased heart rate (open arrowheads). L, left; R, right; EOG, electrooculography; EMG, electromyography; EKG, electrocardiogram; $\mathrm{SpO}_{2}$, peripheral oxygen saturation. 
larly hostile to brain function. Exposure to intermittent hypoxia in rodents results in impaired executive function, excessive sleepiness, and sensitivity to sleep deprivation. ${ }^{71-74}$ There is evidence of neuronal injury in the hippocampus, ${ }^{75,76}$ the basal forebrain, ${ }^{77}$ and the wake-promoting catecholaminergic system. ${ }^{78}$ The mediating mechanisms include free radical injury, lipid peroxidation, induction of nitric oxide synthase, platelet activation, and apoptosis. ${ }^{79-81}$ However, oxidative stress, especially modest hypoxia, may have a protective effect on the brain and cardiovascular system by activating gene programs that induce vascular remodeling as well as other protective responses; thereby, engendering resilience in the brain (known as ischemic preconditioning). ${ }^{82}$

OSA is related to the surrogate index of stroke. Moderate-tosevere OSA is associated with silent ischemic changes, including white matter changes and lacunae as well as cerebral microbleeds. ${ }^{83-86}$ Carotid and intracranial atherosclerosis are also accelerated in OSA. ${ }^{87,88}$ It is unclear whether continuous positive airway pressure (CPAP) has a therapeutic effect on these changes. $^{89}$

Hypertension and insulin resistance might mediate the development of stroke in OSA. Moderate-to-severe OSA is significantly associated with prevalent and incident hypertension in a severity-dependent manner, ${ }_{1}^{90,91}$ and is highly prevalent in patients with resistant hypertension. ${ }^{92}$ Effective CPAP therapy, alone or in addition to antihypertensive medication, significantly reduces blood pressure. ${ }^{93-95}$ OSA may also increase the risk for development of type 2 diabetes by mechanisms such as increased insulin resistance and high cortisol secretion. ${ }^{12,96}$ In a 6-month parallel trial, the CPAP group achieved a greater decrease in $\mathrm{HbA} 1 \mathrm{c}(-0.4 \%$; $95 \%$ confidence interval [Cl], $-0.7 \%$ to $-0.04 \%$ ) than the control group. ${ }^{97}$ Continuously supervised CPAP therapy (7.92 hr/night) improved glycemic control and insulin resistance. ${ }^{98}$ However, the CPAP effect on glycemic control is less consistent than its effect on blood pressure. Concomitant obesity might have a stronger effect than OSA, not mitigated by CPAP therapy.

OSA is also associated with the risk for cardioembolism. Nearly $40 \%$ of symptomatic atrial fibrillation events are seen between midnight and 8:00 AM. ${ }^{99}$ People with OSA have four times the odds of atrial fibrillation (odds ratio [OR], 4.02; 95\% $\mathrm{Cl}, 1.03$ to 15.74$).{ }^{100}$ Nocturnal oxygen desaturation is an independent risk factor for new onset atrial fibrillation. ${ }^{101}$ In a recent cohort study of 6,841 patients, OSA diagnosis and severity were associated with atrial fibrillation (hazard ratio [HR], 1.55; $95 \% \mathrm{Cl}, 1.21$ to 2.00 ) during a follow-up of 12 years. ${ }^{102}$ Furthermore, OSA may potentiate the risk of cardioembolism or stroke in patients with atrial fibrillation. ${ }^{103,104}$ Several observa- tional studies found an improvement or resolution of cardiac arrhythmia and atrial fibrillation after CPAP therapy. ${ }^{105,106}$

In addition, sleep apnea is associated with inflammation, ${ }_{1}^{107-110}$ endothelial dysfunction, ${ }^{111,112}$ hypercoagulability, ${ }^{113-115}$ and cerebral hemodynamic changes. ${ }^{116-118}$ The overall findings suggest that OSA contributes to the development of stroke through various mechanisms downstream to intermittent hypoxia, sleep fragmentation, and hemodynamic swings. ${ }^{9,12,46,70}$

\section{Observational findings}

Sleep apnea is exceedingly common in the acute stroke setting, present in 50\% to $70 \%$ of subjects with acute stroke or transient ischemic attacks, which is a higher frequency than observed in control groups. ${ }^{119-122}$ However, OSA and stroke share risk factors such as male sex, obesity, old age, hypertension, and smoking. ${ }^{62,65,66,68} \mathrm{An}$ independent association between the two conditions was supported by large scale epidemiological studies including the Sleep Heart Health Study and the Wisconsin Sleep Cohort Study. ${ }^{48,123}$ In these studies, OSA with an apnea-hypopnea index $(\mathrm{AHI}) \geq 20 / \mathrm{hr}$ or $>11 / \mathrm{hr}$ was related to prevalent stroke, with an OR of $4.31(95 \% \mathrm{Cl}, 1.31$ to 14.15) and $1.58(95 \% \mathrm{Cl}, 1.02$ to 2.46$)$, respectively, when adjusted for age, sex, weight, blood pressure, smoking, and other confounders. Prospective cohort studies in clinical or general populations followed, and the major findings are summarized in Table $1 .{ }^{47-}$ $49,124-128$

In the first study on the temporal relationship between OSA and stroke in the general population (from the Wisconsin Sleep Cohort), the causal association was attenuated (OR, 3.08; 95\% $\mathrm{Cl}, 0.74$ to 12.81) when adjusted for age, sex, and body mass index. ${ }^{48}$ The younger age of the cohort (mean age, $47 \pm 8$ years old) and a low incidence of stroke (1.3 per 1,000 person-years) probably weakened the statistical power. In the Sleep Heart Health Study ( $n=5,422$; stroke incidence, 4.4 per 1,000 personyears), men with moderate-to-severe OSA (AHI $>19 / \mathrm{hr}$ ), but not women, had a higher risk for ischemic stroke during follow-up (median, 8.7 years; $\mathrm{HR}, 2.86 ; 95 \% \mathrm{Cl}, 1.1$ to 7.4 ). The lack of association in women was explained by insufficient statistical power (lower stroke incidence in women); the relatively shorter duration of OSA exposure (due to the later, usually postmenopausal, onset in women) ${ }_{i}^{129}$ the higher rate of OSA progression along with aging during the follow-up, leading to a considerable probability of misclassification (OSA vs. control, or OSA severity); and the stronger effects of wellknown vascular risk factors. ${ }^{49}$ For elderly people of both sexes (aged 70 to 100 years, $n=394$ ), the risk of incident stroke was significantly higher for severe OSA (AHI $\geq 30 / h r ; H R, 2.52$ ) throughout a 6 -year period of observation, independent of 
Table 1. Studies of obstructive sleep apnea at risk for stroke

\begin{tabular}{|c|c|c|c|c|c|}
\hline Study & Design & Number & Group & Primary outcome ${ }^{*}$ & Risk factor adjustment \\
\hline $\begin{array}{l}\text { Arzt et al. } \\
(2005)^{48}\end{array}$ & $\begin{array}{l}\text { General population cohort, } \\
\text { follow-up at every } 4 \mathrm{yr}\end{array}$ & 1,189 & $A H I>20$ vs. $<5$ & $\begin{array}{l}\text { Incident stroke } \\
\text { OR, } 3.08(0.74-12.81)\end{array}$ & Age, sex, and BMI \\
\hline $\begin{array}{l}\text { Redline } \\
\text { et al. }(2010)^{49}\end{array}$ & $\begin{array}{l}\text { General poulation cohort, } \\
\text { (median) } 8.7 \text { yr follow-up }\end{array}$ & 5,422 & AHI $>19$ vs. $<4$ & $\begin{array}{l}\text { Incident stroke } \\
\text { Men: HR, } 2.86 \text { (1.10-7.39) } \\
\text { Women: HR, } 1.21 \text { (0.65-2.24) }\end{array}$ & $\begin{array}{l}\text { Age, BMI, smoking, blood } \\
\text { pressure, antihypertensives, } \\
\text { diabetes mellitus, and race }\end{array}$ \\
\hline $\begin{array}{l}\text { Marin et al. } \\
(2005)^{125}\end{array}$ & $\begin{array}{l}\text { Clinic (OSA) and general } \\
\text { population (control) co- } \\
\text { hort, } 10.1 \text { yr follow-up }\end{array}$ & 1,010 men & $\begin{array}{c}\text { Untreated severe OSA } \\
\text { (AHI } \geq 30 \text { or } A H I \text { 5-30 with } \\
\text { severe daytime sleepiness) } \\
\text { vs. } \mathrm{AHI}<5\end{array}$ & $\begin{array}{l}\text { Incident composite cardiovascular } \\
\text { events } \\
\text { Non-fatal: OR, } 3.17 \text { (1.12-7.51) } \\
\text { Fatal: OR, } 2.87 \text { (1.17-7.51) }\end{array}$ & $\begin{array}{l}\text { Age, cardiovascular disease, } \\
\text { diabetes mellitus, hypertension, } \\
\text { lipid disorders, smoking, alcohol, } \\
\text { blood pressure, glucose, and lipid } \\
\text { levels }\end{array}$ \\
\hline $\begin{array}{l}\text { Munoz et al. } \\
(2006)^{126}\end{array}$ & $\begin{array}{l}\text { Clinic cohort, (mean) } 4.5 \mathrm{yr} \\
\text { follow-up }\end{array}$ & 394 & $\mathrm{AHI}>30$ vs. $0-29$ & $\begin{array}{l}\text { Incident stroke } \\
\text { HR, } 2.52(1.04-6.10)\end{array}$ & $\begin{array}{l}\text { Sex (distribution of other risk } \\
\text { factors were balanced between } \\
\text { the two groups) }\end{array}$ \\
\hline $\begin{array}{l}\text { Yaggi et al. } \\
(2005)^{47}\end{array}$ & $\begin{array}{l}\text { Clinic cohort, (median) } 3.4 \\
\text { yr follow-up }\end{array}$ & 1,022 & $\mathrm{AHI}>5$ vs. $\mathrm{AHI}<5$ & $\begin{array}{l}\text { Incident stroke or death of any } \\
\text { causes } \\
H R, 1.97(1.12-3.48)\end{array}$ & $\begin{array}{l}\text { Age, race, sex, smoking, alcohol, } \\
\text { BMI, atrial fibrillation, } \\
\text { hypertension, and lipids }\end{array}$ \\
\hline $\begin{array}{l}\text { Yeboah et al. } \\
(2011)^{128}\end{array}$ & $\begin{array}{l}\text { General population cohort, } \\
\text { (mean) } 7.5 \text { yr follow-up }\end{array}$ & 5,338 & $\begin{array}{l}\text { Physician diagnosed OSA vs. } \\
\text { normal control }\end{array}$ & $\begin{array}{l}\text { Incident cardiovascular events } \\
\text { HR, } 2.16 \text { (1.30-3.58) } \\
\text { All-cause mortality } \\
\text { HR, } 2.71(1.45-5.08)\end{array}$ & $\begin{array}{l}\text { Age, gender, race/ethnicity, } \\
\text { smoking, diabetes, total } \\
\text { cholesterol, high-density } \\
\text { lipoprotein, triglyceride, BMI, } \\
\text { alcohol, benzodiazepine/statin/ } \\
\text { antihypertensive use }\end{array}$ \\
\hline $\begin{array}{l}\text { Young et al. } \\
(2008)^{127}\end{array}$ & $\begin{array}{l}\text { General population cohort } \\
18 \text { yr follow-up }\end{array}$ & 1,522 & $\mathrm{AHI}>30$ vs. $\mathrm{AHI}<5$ & $\begin{array}{l}\text { Cardiovascular mortality } \\
\text { HR, } 5.2(1.4-19.2) \\
\text { All-cause mortality } \\
\text { HR, } 3.8(1.6-9.0)\end{array}$ & $\begin{array}{l}\text { Age, sex, BMI, smoking, alcohol, } \\
\text { total cholesterol, and sleep } \\
\text { duration }\end{array}$ \\
\hline
\end{tabular}

$\mathrm{AHI}$, apnea-hypopnea index; OR, odds ratio; BMI, body mass index; HR, hazard ratio; OSA, obstructive sleep apnea.

${ }^{*}$ Adjusted OR or HR (95\% confidence interval).

other vascular risk factors. ${ }^{126}$

Prospective observational studies of clinic-based cohorts, assessing composite cardiovascular events as a primary endpoint, also suggested a role for OSA in the development of stroke. ${ }^{124,125}$ Peker et al. ${ }^{124}$ reported an independent association of OSA with cardiovascular events in a small community sample of men (age, 30 to 69 years old; $n=182$ ) free from prevalent cardiovascular diseases, hypertension, and diabetes. During the 7-year follow-up, the OR for people with OSA having cardiovascular diseases (including stroke) was $4.9(95 \% \mathrm{Cl}, 1.8$ to 13.6), and effective treatment of OSA significantly reduced the risk $(\mathrm{OR}, 0.1 ; 95 \% \mathrm{Cl}, 0.0$ to 0.7$)$. The effect of treatment, as well as the contribution of OSA to cardiovascular event incidence, were demonstrated in a subsequent long-term observational study of a clinical population (mean observation period, 10.1 years; $n=1,656){ }^{125}$ The group of subjects with untreated severe OSA (AHI $\geq 30 / \mathrm{hr}$ or 5 to $29 / \mathrm{hr}$ with severe sleepiness) had a higher hazard for fatal and non-fatal cardiovascular diseases (HR, 2.87 and 3.17, respectively), compared with ageand body mass-matched controls. With an average nightly use of CPAP for at least 4 hours, the risk of incident cardiovascular events among subjects with severe or symptomatic OSA was comparable to that of controls or simple snorers ( $\mathrm{AHI}<5 / \mathrm{hr}$ ). The cardiovascular effects of OSA are not limited to subjects with a severe burden of OSA. A prospective observational study in a clinical population (aged $\geq 50$ years; $n=1,022$ ) free from myocardial infarction or stroke at study entry, found that the presence of OSA ( $\mathrm{AHI} \geq 5 / \mathrm{hr}$ ) increased the risks for outcome events (stroke or death from any cause, $\mathrm{HR}, 1.97 ; 95 \% \mathrm{Cl}, 1.12$ to 3.48 ) during the follow-up (median, 3.4 years). ${ }^{47}$ However, the treatment effect was not substantial, even though a large proportion of OSA subjects had active treatments including meaningful weight reduction (31\% with weight loss of $\geq 10 \%$ body weight), CPAP therapy (58\%) with fair adherence (at least 4 hours of nightly use for $\geq 5$ nights a week), and upper airway surgery (15\%). The increased rates of stroke and death despite OSA treatment can be explained by older age (compared to a previous study ${ }^{125}$ ), with correspondingly increased vascular risk, prolonged exposure to OSA prior to the treatment, a relatively shorter duration of intervention, and changes in treatment effectiveness (weight regained, reduced CPAP adherence, or loss of surgery effect). ${ }^{47}$ The study was not designed a priori to investigate treatment effects. An increased risk of cardiovascular and non-cardiovascular death in the OSA group was also re- 
ported from a longitudinal analysis of the Wisconsin Sleep Cohort and the Multi-Ethnic Study of Atherosclerosis cohort. ${ }^{27,128}$

Summarizing the observational findings, prospective studies largely support a causal relationship between OSA and stroke (Table 1). Recent systematic meta-analyses reported that OSA was significantly associated with incident stroke $(O R, 2.24 ; 95 \%$ $\mathrm{Cl}, 1.57$ to 3.19 ) (relative risk [RR], 2.02; 95\% Cl, 1.40 to 2.10). ${ }^{50,130}$ However a few important issues should be considered. First, the effects of well-established cardiovascular risk factors other than age, including hypertension, diabetes, atrial fibrillation, and smoking, were smaller than that of OSA, which was generally not significant. ${ }^{47,49,125,126}$ Optimal modification or treatment of well-established vascular risk factors was likely to reduce their influences on the outcomes in the study participants. ${ }^{126}$ Second, the observational findings are inherently limited by study design and lack of randomization. The baseline characteristics among groups may differ by undefined factors other than chance. The "healthy adherer" effect, describing a better outcome in subjects compliant with any given intervention due to their health-conscious behavior or lifestyle, might bias the results in favor of CPAP therapy. ${ }^{131,132}$ Studies with randomized designs are required to provide a better understanding of the causal relationship between OSA and stroke, as well as the therapeutic efficacy of CPAP in the prevention of stroke.

\section{Randomized clinical trials}

Well-designed randomized clinical trials (RCTs) of CPAP therapy for primary prevention of clinical outcomes such as stroke, coronary heart disease, or atrial fibrillation are scarce. ${ }^{133}$ In an RCT, feasibility and study design are critically influenced by the expected rate of the primary endpoint, the predicted efficacy (and precision in application) of therapy, and the estimated duration of intervention, all of which affect the sample size required for sufficient statistical power. To examine the effects of interventions on hard clinical endpoints (e.g., stroke in OSA) requires a larger sample size and longer period of observation than needed for trials with surrogate endpoints (e.g., blood pressure or inflammation in OSA). Therefore, to assess the effect of therapy (e.g., CPAP) on clinical outcomes, secondary prevention studies may be more feasible. ${ }^{134,135}$

Recently the results from two RCTs were reported, testing the long-term efficacy of CPAP therapy for the prevention of cardiovascular events in subjects with established cardiovascular disease (coronary heart disease or stroke) and OSA. ${ }^{60,61}$ The Sleep Apnea Cardiovascular Endpoint (SAVE) trial was a multinational RCT including 2,717 non-sleepy subjects with moderate-to-severe OSA ( $\mathrm{AHI} \geq 15 / \mathrm{hr}$, but not with severe hypoxemia [oxygen desaturation $<80 \%$ for $>10 \%$ of recording time]) and established stroke or cardiovascular disease, who were subsequently randomized either to usual care with CPAP therapy or to usual care alone, and were followed for a mean period of 3.7 years. ${ }^{60}$ The study tested the hypothesis that additional CPAP therapy reduced the risk of future cardiovascular events (a composite of vascular mortality, myocardial infarction, stroke, or hospitalization for vascular events). During the follow-up, the CPAP therapy did not effectively lower the incidence of predefined events compared with the usual care $(H R$, $1.10 ; 95 \% \mathrm{Cl}, 0.91$ to 1.32$)$. In the CPAP group $(n=1,346)$, the adherence was only 3.3 hours per night on average, and fair ( $\geq 4 \mathrm{hr} / \mathrm{night}$ ) in less than half of the subjects (42\%). During the run-in period of a week with sham CPAP that was introduced to maximize the treatment adherence of the study participants, the required threshold of minimal adherence was an average of 3 hours per night, equivalent to 50\% adherence in those who sleep 6 hours daily. In the prespecified propensity-scorematched analysis to compare the group with fair CPAP adherence $(n=561)$ with matched controls, the reduction in the composite endpoint was not significant $(\mathrm{HR}, 0.80 ; 95 \% \mathrm{Cl}$, 0.60 to 1.07), but a lower risk of stroke was found ( $H R, 0.56$; $95 \% \mathrm{Cl}, 0.32$ to $1.00 ; P=0.05)$. Another RCT, the Randomized Intervention with CPAP in CAD and OSA (RICCADSA) trial, was performed in patients with coronary artery disease and concomitant non-sleepy OSA ( $n=244 ; A H I \geq 15 / h r) .{ }^{61}$ During the follow-up (median, 56.9 months), the incidence of the primary composite endpoint (repeat revascularization, myocardial infarction, stroke, or cardiovascular mortality) was not different between the groups with and without CPAP therapy, but based on the per protocol analysis, the risk was significantly lower in the CPAP adherent group (nightly use $\geq 4$ hours) than in the non-compliant group or the untreated group (HR, 0.29; 95\% $\mathrm{Cl}, 0.10$ to 0.86$)$.

Both the large (SAVE) and the small scale (RICCADSA) RCTs failed to demonstrate efficacy of CPAP therapy. Negative findings in such high-profile trials underscore the need for future trials, and are vital contributors to recognizing and addressing the key factors to be considered in the design of future studies. ${ }^{136,137}$ Several important aspects should be discussed in this context. Both trials included only non-sleepy OSA for ethical reasons (the expected harm to sleepy subjects if included but untreated). Excessive daytime sleepiness is a marker of higher levels of inflammation, insulin resistance, and blood pressure, compared with non-sleepy OSA. ${ }^{138-140}$ By excluding sleepy subjects, the study sample was limited to a potentially lower-risk group, thus reducing its statistical power. Preceding RCTs on non-sleepy OSA populations have demonstrated that CPAP therapy is not effective in reducing blood pressure and pre- 
venting cardiovascular risk or events including incident hypertension, despite improvements in subjective sleepiness. ${ }^{141-145}$ Therefore the lack of CPAP efficacy in trials performed with non-sleepy subjects cannot be generalized to severe or symptomatic OSA populations.

Another major issue is the therapeutic effectiveness of CPAP in these trials. CPAP adherence is a critical factor in therapeutic effectiveness. In the SAVE trial, the average nightly use was 3.3 hours, 20\% of the subjects did not use CPAP at all, and only $42 \%$ used CPAP for at least 4 hours a night. The 4 -hour threshold is an insurance-payment driven criterion widely enforced in the United States, which has gradually morphed into a clinical standard. The flaw in this sort of "criteria creep" is emphasized. Such a low adherence may have contributed to the null findings, as the residual apnea burden (see below) is substantial. Adherence to CPAP has modified efficacy in previous trials: $:^{145-147}$ the higher the adherence, the better the outcome. A dose-response association between CPAP adherence and cardiovascular outcome was found in the SAVE and RICCADSA trials, in which CPAP adherence was related to a lower risk of stroke ( $\mathrm{HR}, 0.56 ; 95 \% \mathrm{Cl}, 0.32$ to 1.00$)$ or cardiovascular endpoints ( $\mathrm{HR}, 0.29 ; 95 \% \mathrm{Cl}, 0.10$ to 0.86$){ }^{60,61}$ However these findings came from secondary or on-treatment analysis, possibly biased by multiple comparisons or a healthy adherer effect. ${ }^{131,132}$ In addition to adherence, the timing and the duration of CPAP-off periods affect therapeutic effectiveness. ${ }^{148-152}$ The CPAP-off time is likely to predominate in the latter half of the night, when REM sleep is prevalent. OSA events during REM sleep are generally prolonged and associated with severe oxygen desaturation. Sleep apnea during REM, but not during NREM sleep, has been associated with hypertension, non-dipping of nocturnal blood pressure, and insulin resistance, even in subjects not considered to have OSA (AHI $<5 / \mathrm{hr}$ ). ${ }^{153-156}$ In recent observational finding from the Sleep Heart Health Study, severe REM OSA (AHI during REM sleep $\geq 30 / \mathrm{hr}$ ) was associated with a higher incidence of cardiovascular events in the group with prevalent cardiovascular disease. ${ }^{157}$ The cardiovascular effects of REM OSA have several important implications. The timing and duration of the CPAP-off periods as well as the subjects' sleep should be documented to define and interpret the effectiveness of intervention. The residual apnea burden, including REM OSA, is directly influenced by the proportion and timing of CPAP-on and -off periods. ${ }^{148-150}$ In future trials, a predefined secondary analysis of REM OSA should be performed, considering its significant cardiovascular effects and prevalence. ${ }^{158}$ REM OSA in subjects with $\mathrm{AHI}$ of $<5 / \mathrm{hr}$ may bias the results of RCTs, especially secondary prevention trials. ${ }^{157}$ From a diagnostic standpoint, simple cardiorespiratory moni- toring devices, for example, a portable device consisting of airflow and oximetry, should not be used in future trials. Such a home kit cannot reliably detect REM OSA, central sleep apnea, and periodic limb movements (PLMs). ${ }^{159}$ The latter two conditions are not only commonly present in high risk populations for cardiovascular events (such as the elderly or subjects with established cardiovascular diseases or stroke), but also increase the cardiovascular risk of these individuals. ${ }^{160-164}$

Finally, there is clear evidence that what is called OSA is a complex pathophysiological condition, with multiple and often interacting disease drivers. ${ }^{165-167}$ These include upper airway collapsibility, impaired negative pressure response, reduced arousal threshold and high loop gain. The first three become irrelevant when the airway is adequately supported, but high loop gain will cause ongoing respiratory control instability and a high residual apnea burden or treatment intolerance. The risk of high loop gain is increased in those with cardiovascular comorbidities, setting the stage for impaired therapeutic responses. ${ }^{166}$ Multi-modal therapy, such as low dose acetazolamide plus $\mathrm{CPAP}_{1}{ }^{168,169}$ may reasonably be considered in future clinical trials. The quality of data, specifically direct visualization of respiratory waveforms from current generation CPAP devices, can also detect residual disease burden and help identify those who could benefit from multi-modal therapy. ${ }^{170}$ The question should not be whether CPAP is beneficial, but whether effective sleep therapy is beneficial.

Previous RCTs on cardiovascular outcomes usually adopted composite endpoints, mainly due to considerations of feasibility and statistical power. However, for future trials, therapeutic efficacy needs to be tested separately for each type of cardiovascular endpoint. Stroke is a primary candidate for this purpose. In CPAP trials and observational studies, OSA was more strongly related to stroke than to other cardiovascular diseases. In the SAVE trial, CPAP adherence led to the reduced risk of stroke ( $\mathrm{HR}, 0.56 ; 95 \% \mathrm{Cl}, 0.32$ to 1.00$)$, and untreated OSA in women was associated with an increased incidence of cardiovascular events, particularly stroke (HR for stroke, $6.44 ; 95 \%$ $\mathrm{Cl}, 1.46$ to 28.3; and HR for coronary heart disease, 1.77; $95 \%$ $\mathrm{Cl}, 0.76$ to 4.09), which is concordant with the findings of the Sleep Heart Health Study concerning the relationship between OSA and stroke occurrence. ${ }^{49,60,171}$

To summarize, we caution against discarding the benefit of CPAP therapy for the prevention of stroke and other cardiovascular events in OSA on the basis of results from the currently available RCTs. The overall findings suggest what really matters is the therapeutic effectiveness, which is determined by CPAP adherence, CPAP efficacy, apnea burden, ${ }^{148-150}$ and possibly disease phenotype. ${ }^{165-167}$ Apnea burden is driven by residual or 
Table 2. Studies between sleep duration and risk of stroke or mortality

\begin{tabular}{|c|c|c|c|}
\hline Study & Design & Number & Major findings* \\
\hline Chen et al. (2008) $)^{172}$ & $\begin{array}{l}\text { Cohort } \\
7.5 \text { yr follow-up }\end{array}$ & $\begin{array}{l}93,175 \\
\text { women }\end{array}$ & $\begin{array}{l}\leq 6 \mathrm{hr} \text { of sleep } \\
: \text { RR for ischemic stroke, } 1.22(1.03-1.44) \\
8 \mathrm{hr}, 9 \mathrm{hr} \text { of sleep } \\
: \text { RR for ischemic stroke, } 1.14(0.97-1.33), 1.24(1.04-1.47)\end{array}$ \\
\hline Helbig et al. (2015) ${ }^{173}$ & $\begin{array}{l}\text { Cohort } \\
14 \text { yr (mean) follow-up }\end{array}$ & 17,604 & $\begin{array}{l}\leq 5 \mathrm{hr} \text { of sleep } \\
: \text { HR for stroke, } 1.44(1.01-2.06) \\
\geq 10 \mathrm{hr} \text { of sleep } \\
: \text { HR for stroke, } 1.63(1.16-2.29)\end{array}$ \\
\hline Kawachi et al. (2016) ${ }^{181}$ & $\begin{array}{l}\text { Cohort } \\
17 \text { yr follow-up }\end{array}$ & 27,896 & $\begin{array}{l}\geq 9 \mathrm{hr} \text { of sleep } \\
: \text { HR for stroke mortality, } 1.51(1.16-1.97) \\
: \text { HR for ischemic stroke mortality, } 1.65(1.16-2.35)\end{array}$ \\
\hline Leng et al. $(2015)^{51}$ & $\begin{array}{l}\text { Cohort } \\
9.5 \text { yr follow-up }\end{array}$ & 9,692 & $\begin{array}{l}\geq 8-9 \text { hr of sleep } \\
\text { : HR for stroke, } 1.46(1.08-1.98)\end{array}$ \\
\hline Pan et al. (2014) ${ }^{178}$ & $\begin{array}{l}\text { Cohort } \\
14.7 \text { yr follow-up }\end{array}$ & 63,257 & $\begin{array}{l}\leq 5 \mathrm{hr} \text { of sleep } \\
: \text { HR for stroke mortality, } 1.25(1.05-1.50) \\
\geq 9 \text { hr of sleep } \\
: \text { HR for stroke mortality, } 1.54(1.28-1.85)\end{array}$ \\
\hline Qureshi et al. (1997) & $\begin{array}{l}\text { Cohort } \\
10 \text { yr follow-up }\end{array}$ & 7,844 & $\begin{array}{l}>8 \mathrm{hr} \text { of sleep } \\
\text { : RR for stroke, } 1.5(1.1-2.0) \\
>8 \mathrm{hr} \text { of sleep with daytime somnolence } \\
\text { : RR for stroke, } 1.9(1.2-3.1)\end{array}$ \\
\hline von Ruesten et al. (2012) $)^{174}$ & $\begin{array}{l}\text { Cohort } \\
7.8 \mathrm{yr} \text { (mean) follow-up }\end{array}$ & 23,620 & $\begin{array}{l}<6 \mathrm{hr} \text { of sleep } \\
: \text { HR for stroke, } 2.06(1.18-3.59)\end{array}$ \\
\hline He et al. $(2017)^{52}$ & $\begin{array}{l}\text { Meta-analysis } \\
\text { 7.8-14.7 yr follow-up }\end{array}$ & 528,653 & $\begin{array}{l}\text { RR for stroke (7 hr as reference) } \\
: 4 \mathrm{hr}, 1.17(0.99-1.38) ; 5 \mathrm{hr}, 1.17(1.00-1.37) ; 6 \mathrm{hr}, 1.10 \text { (1.00-1.21); } 8 \mathrm{hr}, 1.17 \\
(1.07-1.28) ; 9 \mathrm{hr}, 1.45(1.23-1.70) ; 10 \mathrm{hr}, 1.64(1.4-1.92)\end{array}$ \\
\hline Li et al. (2016) ${ }^{175}$ & $\begin{array}{l}\text { Meta-analysis } \\
3-18 \text { yr follow-up }\end{array}$ & 522,163 & $\begin{array}{l}\text { Short sleep duration (7 hr as reference) } \\
\text { : RR for stroke, } 1.07 \text { (1.02-1.12) for each 1-hr shorter } \\
\text { Long sleep duration (7 hr as reference) } \\
\text { : RR for stroke, } 1.17(1.14-1.20) \text { for each 1-hr increase } \\
\text { : RR for stroke mortality, } 1.17(1.13-1.20) \text { per 1-hr increase }\end{array}$ \\
\hline
\end{tabular}

$R R$, relative risk; $H R$, hazard ratio.

*Adjusted HR or RR (95\% confidence interval).

emergent sleep apnea during CPAP-on and-off periods along with the duration of CPAP-off periods. ${ }^{150-152,170}$ In future trials for primary and secondary prevention in OSA, we need to adopt methods to determine the therapeutic effectiveness by measuring apnea burden, and to test whether effective therapy (defined by minimal or sufficiently low apnea burden, e.g., measured average $\mathrm{AHI}<5$ over the entire treatment period including both CPAP-on and -off state in sleep) reduces the risk of stroke and other cardiovascular events.

\section{Sleep duration and insomnia}

\section{Sleep duration}

The relationship between sleep duration and stroke incidence is $\mathrm{U}$-shaped in general; the risk for stroke is elevated in both short and long sleep groups. ${ }^{172-174}$ In a recent meta-analysis $(n=559,252)$, the pooled HR for stroke was $1.15(95 \% \mathrm{Cl}, 1.07$ to 1.24$)$ for short sleep and $1.45(95 \% \mathrm{Cl}, 1.30$ to 1.62$)$ for long sleep duration. ${ }^{51}$ In another study, the pooled RR for stroke was $1.07\left(95 \% \mathrm{Cl}_{1} 1.02\right.$ to 1.12$)$ and $1.17(95 \% \mathrm{Cl}, 1.14$ to 1.20$)$ for each 1-hour decrease and increase in sleep duration, respectively. ${ }^{175}$

Short sleep, commonly defined as $<5$ to 6 hours of nocturnal sleep, increases the risks of stroke, coronary heart disease, and death (Table 2). ${ }^{52,173,175-180}$ In a large-scale prospective study of older women (Women's Health Initiative Study; age, 50 to 79 years; $n=93,175$ ), short sleep ( $\leq 6$ hours) was associated with ischemic stroke $(\mathrm{HR}, 1.22 ; 95 \% \mathrm{Cl}, 1.03$ to 1.44$)$ in the group free from cardiovascular diseases and diabetes at the baseline. ${ }^{172}$ Despite the large sample size, the study was limited by the participants' characteristics, as enrollment was restricted to postmenopausal women. In the European Prospective Investigation into Cancer and Nutrition-Potsdam Study $(n=23,620$; age, 35 to 65 years; men 38.6\%), subjects with short sleep $(<6$ hours) had a significantly increased risk for stroke (HR, 2.06; $95 \% \mathrm{Cl}, 1.18$ to 3.59 ) during the 8-year follow-up. ${ }^{174}$ In anoth- 
er population-based prospective study ( $n=17,604$; age, 25 to 74 years; mean follow-up, 14 years), short sleep ( $\leq 5$ hours) was significantly associated with stroke in men $(\mathrm{HR}, 1.44 ; 95 \% \mathrm{Cl}$, 1.01 to 2.06$).{ }^{173}$

Long sleep duration (more than 9 hours of sleep) is also associated with stroke and cardiovascular mortality. ${ }^{51,178,179,181,182}$ Qureshi et al. ${ }^{182}$, using the First National Health and Nutrition Examination Survey (NHANES I), reported that stroke risk was higher in people who reported sleeping for $>8$ hours than for those who slept 6 to 8 hours (RR, 1.5; 95\% Cl, 1.1 to 2.1$)$. In a recent population-based prospective study of 9,692 stroke-free participants, long sleep ( $\mathrm{HR}, 1.46 ; 95 \% \mathrm{Cl}, 1.08$ to 1.98$)$, but not short sleep (HR, 1.18; $95 \% \mathrm{Cl}, 0.91$ to 1.53$)$, was associated with a higher risk of stroke. ${ }^{51}$

The association between sleep duration and stroke mortality has been assessed in several prospective studies ${ }^{17,183}$ and meta-analyses. ${ }^{52,175,184}$ The Singapore Chinese Health Study ( $n=63,257$ ) showed that long ( $\geq 9$ hours) and short ( $\leq 5$ hours) sleep duration (compared with 7 hours of sleep) were significantly associated with increased risk for total stroke mortality ( $\mathrm{HR}, 1.54 ; 95 \% \mathrm{Cl}, 1.28$ to 1.85 ; and $\mathrm{HR}, 1.25 ; 95 \% \mathrm{Cl}, 1.05$ to 1.50 , respectively). ${ }^{178} \mathrm{~A}$ meta-analysis showed that stroke mortality increased at either end of the sleep duration range. ${ }^{184}$ However, other studies have found that the risk of stroke mortality increased only for long sleep duration, not for short sleep. $52,175,181,183$

When interpreting the relationship between sleep duration and the risk of stroke or mortality, a few issues need to be considered. First, in most epidemiologic studies the assessment of sleep duration was based on self-report, not on objective measurement. Although self-reported sleep duration generally correlates to a degree with the duration measured by actigraphy or polysomnography, ${ }_{1}^{185,186}$ reported sleep duration is systematically over-estimated, especially in short sleepers, compared with objectively measured sleep duration. ${ }^{187}$ Second, long sleep has a greater effect on mortality than short sleep, ${ }^{52,181,188}$ which can be explained by differences in the driving forces for each end of the sleep spectrum. In contrast to short sleep, which commonly results from voluntary sleep curtailment due to social requirements or individual preferences, long sleep indicates an increased need for sleep, especially in the elderly, influenced by comorbid medical conditions such as chronic devastating illness or inflammation. ${ }^{52,189-191}$ Short sleep is a modifiable behavioral risk factor with a small but significant impact on cardiovascular morbidity and mortality. Long sleep is an indicator of comorbid medical conditions that confer higher mortality and vascular risk. A longitudinal observational study of the Whitehall II Cohort demonstrated the differential effects of short and long sleep: a decrease in sleep duration was associated with increased cardiovascular mortality, while an increase was related to non-cardiovascular death. ${ }^{192}$

The linking mechanisms between short sleep and cardiovascular events include obesity, impaired glucose metabolism, hypertension, and dyslipidemia. Sleep loss contributes to the development of obesity or weight gain by disturbing the balance between energy intake and expenditure. Sleep deprivation leads to increased levels of the appetite stimulating hormone ghrelin and reduced levels of the anti-appetite hormone leptin. ${ }^{193,194}$ Furthermore, reduced physical activity associated with sleep deprivation leads to weight gain by decreasing energy expenditure. ${ }^{195,196}$ Short sleep is also associated with sympathetic overactivity ${ }_{1}^{197}$ which leads to impaired glucose metabolism, ${ }^{180,198}$ hypertension, and non-dipping of blood pressure. ${ }^{176,199,200}$ Sleep loss alters lipid metabolism. ${ }^{177,201,202}$ Insufficient sleep activates inflammatory pathways, as indicated by increased levels of C-reactive protein and interleukin- $6 .{ }^{203,204}$

Long sleep duration has been suggested as a potential marker for subsequent stroke risk. ${ }^{51,52,175,181,182}$ The linking mechanisms between long sleep and stroke are still elusive, but increased inflammation and abnormal lipid profiles in long sleepers have recently been reported. ${ }^{202,205}$ Long sleep has been associated with cardiovascular conditions including carotid artery atherosclerosis, ${ }^{206}$ atrial fibrillation, ${ }^{207,208}$ and white matter hyperintensities. ${ }^{209}$

In summary, both short and long sleep duration are associated with a higher risk for stroke and mortality. Each end of the sleep duration spectrum has different implications. Short sleep confers an increased risk for cardiovascular events and mortality, via effects on blood pressure, glucose and lipid metabolism. ${ }^{52,175,210,211}$ Long sleep is often an epiphenomenon of comorbidities that are commonly associated with increased sleep fragmentation, depressive symptoms, and poor general health. ${ }^{212}$ The effects of sleep duration can have substantial long-term consequences, considering the increasing longevity of humans. Interventions such as sleep extension in short sleepers might reduce the cardiovascular risks. Simple measures to cope with sleep debt such as napping or weekend sleep extension might have a meaningful impact at the population level. Recent studies found that weekend catch-up sleep was associated with a lower risk of hypertension and obesity. ${ }^{213,214}$

\section{Insomnia}

Insomnia is prevalent in approximately $10 \%$ to $20 \%$ of the adult population, with approximately 50\% having a chronic form. ${ }^{215}$ Chronic insomnia disorder is characterized by a complaint of difficulty initiating sleep and maintaining sleep, and 
Table 3. Studies of insomnia, PLMS, RLS as a prognostic factor for stroke and mortality

\begin{tabular}{|c|c|c|c|}
\hline Study & Design & Number & Major findings* \\
\hline \multicolumn{4}{|l|}{ Insomnia } \\
\hline Chien et al. $(2010)^{217}$ & $\begin{array}{l}\text { Cohort } \\
15.9 \text { yr (median) follow-up }\end{array}$ & 3,430 & $\begin{array}{l}\text { RR for CAD/stroke, } 1.8(1.0-3.1) \\
\text { RR for mortality, } 1.7(1.2-2.5)\end{array}$ \\
\hline Phillips et al. $(2007)^{219}$ & $\begin{array}{l}\text { Cohort } \\
6 \text { yr follow-up }\end{array}$ & 11,863 & $\begin{array}{l}\text { OR for hypertension, } 1.2(1.0-1.3) \\
\text { OR for CVD, } 1.5(1.1-2.0)\end{array}$ \\
\hline Vgontzas et al. (2009) $)^{220}$ & Cross-sectional & 1,741 & $\begin{array}{l}<5 \text { hr vs. }>6 \text { hr of sleep } \\
: \text { HR for hypertension, } 5.1 \text { (2.2-11.8); OR for diabetes, } 3.0 \text { (1.2-7.0) }\end{array}$ \\
\hline Wu et al. $(2014)^{53}$ & $\begin{array}{l}\text { Cohort } \\
4 \text { yr follow-up }\end{array}$ & 21,438 & $\begin{array}{l}\text { Insomniacs vs. non-insomniacs } \\
\text { : adjusted HR for stroke, } 1.54(1.38-1.72)\end{array}$ \\
\hline \multicolumn{4}{|l|}{ PLMS } \\
\hline Kendzerska et al. (2014) 225 & $\begin{array}{l}\text { Retrospective } \\
5.7 \mathrm{yr} \text { (median) follow-up }\end{array}$ & 10,149 & $\begin{array}{l}\text { PLMI } 13.4 \text { vs. } 0 \\
\text { : OR for stroke, } 1.01 \text { (0.94-1.09); OR for mortality, } 1.05 \text { (1.02-1.07) }\end{array}$ \\
\hline Koo et al. $(2011)^{55}$ & $\begin{array}{l}\text { Cohort } \\
4.4 \text { yr follow-up }\end{array}$ & $\begin{array}{l}2,911 \\
\text { men }\end{array}$ & $\begin{array}{l}\text { PLMI }>30 \text { vs. }<5 \\
: \text { OR for CVD, } 1.25(1.00-1.56)\end{array}$ \\
\hline \multicolumn{4}{|l|}{ RLS } \\
\hline Elwood et al. $(2006)^{231}$ & $\begin{array}{l}\text { Cohort } \\
10 \text { yr follow-up }\end{array}$ & $\begin{array}{l}1,874 \\
\text { men }\end{array}$ & OR for stroke, 1.67 (1.07-2.60) \\
\hline Molnar et al. $(2016)^{232}$ & $\begin{array}{l}\text { Cohort } \\
8.1 \text { yr follow-up }\end{array}$ & 7,392 & HR for stroke, 3.89 (3.07-4.94) \\
\hline Szentkirályi et al. $(2013)^{233}$ & $\begin{array}{l}\text { Cohort } \\
6-11 \text { yr follow-up }\end{array}$ & $\begin{array}{l}\text { DHS: } 1,312 \\
\text { SHIP: } 4,308\end{array}$ & $\begin{array}{l}\text { OR for stroke } \\
\text { DHS: } 1.59(0.17-15.16) \\
\text { SHIP: } 1.20(0.46-3.17)\end{array}$ \\
\hline Winkelman et al. $(2008)^{230}$ & Cross-sectional & 3,433 & $\begin{array}{l}\text { OR for hypertension, } 1.3 \text { (0.9-1.8) } \\
\text { OR for CAD/stroke, } 2.4 \text { (1.6-3.7) }\end{array}$ \\
\hline Winter et al. $(2013)^{234}$ & $\begin{array}{l}\text { Cohort } \\
6 \text { yr follow-up }\end{array}$ & 48,938 & $\begin{array}{l}\text { OR for stroke (women), } 1.29 \text { (0.91-1.82) } \\
\text { OR for CVD mortality (men), } 1.22(0.87-1.70)\end{array}$ \\
\hline
\end{tabular}

PLMS, periodic limb movements during sleep; RLS, restless leg syndrome; RR, relative risk; CAD, coronary artery disease; CVD, cardiovascular disease; HR, hazard ratio; OR, odds ratio; PLM, periodic limb movement; PLMI, periodic limb movement index; DHS, Dortmund Health Study; SHIP, Study of Health in Pomerania. ${ }^{*}$ Adjusted RR, OR, or HR (95\% confidence interval).

waking up earlier than desired. The diagnosis of chronic insomnia requires occurrences on at least three nights per week for at least 3 months. ${ }^{216}$ Insomnia was found to be a risk factor for cardiovascular events and death in several studies. ${ }^{190,217}$

Sleep questionnaire-based studies have reported a significant association between insomnia symptoms and cardiovascular outcomes. ${ }^{218}$ In a prospective study of 11,863 participants, subjective insomnia complaints were associated with an increased risk of hypertension and cardiovascular disease. ${ }^{219} \mathrm{~A}$ large study of 21,438 subjects with insomnia and 64,314 matched controls found that the insomnia group had a 54\% higher risk for stroke over a 4-year follow-up period than the control group..$^{53}$ However, these studies had the limitation that the diagnosis of insomnia was based solely on self-reported assessments or questionnaires for insomnia complaints, meaning that the sleep latency and time of being awake after sleep onset were generally overestimated.

Insomnia with objective short sleep duration $(<5$ hours on polysomnography), suggested as the most biologically vulnerable phenotype, carries a higher risk for impaired heart rate variability, hypertension, diabetes, neurocognitive impairment, and mortality, compared with insomnia with longer objective sleep (Table 3). ${ }^{11,220-222}$ Insomnia with objective short sleep may show better response to biological treatments, whereas insomnia with objective normal sleep may show better responses to psychological interventions than to biological treatments. ${ }^{11} \mathrm{El}-$ evated sympathetic and hypothalamic-pituitary-adrenal axis activity has been proposed as a mechanism for the cardiovascular effect of insomnia. ${ }^{11,220}$

\section{Periodic limb movements during sleep and restless legs syndrome}

The defining feature of PLMS is periodic episodes of repetitive, highly stereotyped limb movements during sleep, which mostly occur in the lower extremities and can be associated with cor- 


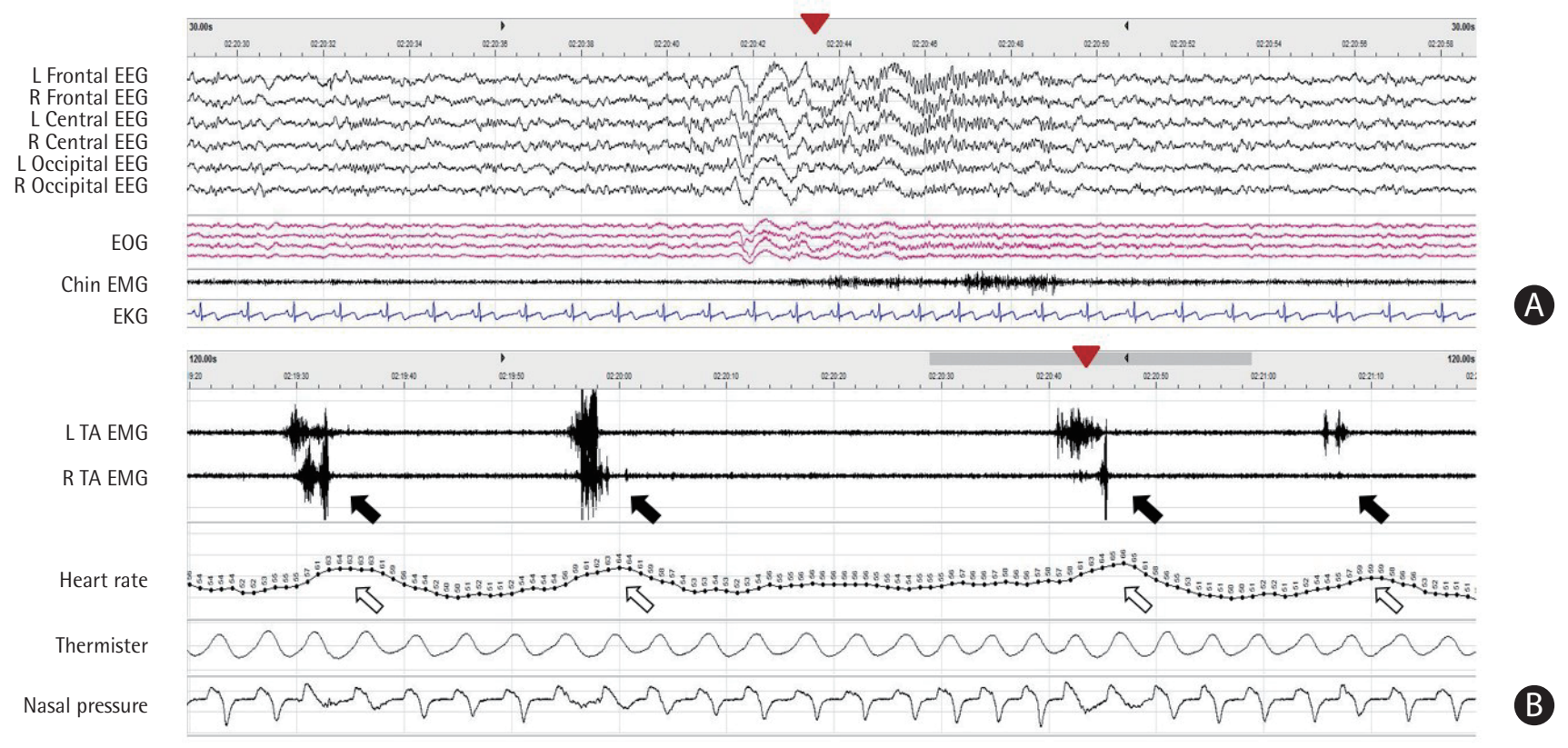

Figure 3. Periodic limb movements during sleep. (A) Electroencephalography (EEG) plots for 30-second epoch. Arousal (arrowhead in panel A) is accompanied by periodic limb movement (arrowhead in panel B) during stage 2 rapid-eye-movement (REM) and non-REM sleep. The closed arrowheads in panels A and B indicate the same time. (B) Movement event plots for 2-minute epoch. Heart rate surges (open arrows) are associated with periodic brief electromyography (EMG) bursts in left or right tibialis anterior (close arrows). L, left; R, right; EOG, electrooculography; EKG, electrocardiogram; TA, tibialis anterior.

tical arousal (Figure 3). ${ }^{216}$ The presence and severity of PLMS is determined by the average number of PLMs per hour of sleep (PLM index). PLM is commonly present in the general population (4.3\% to $9.3 \%$ with PLM index $>15 / \mathrm{hr}$ ) and even more commonly in restless legs syndrome (RLS) patients (80\% to $88 \%$ with PLM index $>5 / h r){ }^{223,224}$ PLM is not specific for RLS, as it is commonly seen with increasing age and in other medical disorders. ${ }^{224}$ A positive relationship between PLM and cardiovascular events or mortality has been demonstrated in observational studies, and a greater risk attributed to PLM combined with arousals. ${ }^{55,164,225,226}$ PLM with arousal induces an abrupt increase in blood pressure and heart rate through sympathetic overshoot. ${ }^{227,228}$

RLS is a chronic sensorimotor disorder characterized by an irresistible urge to move the limbs, which is usually worse at rest, occurs predominantly in the evening or night time, and is relieved by movement such as walking or stretching. ${ }^{216,229}$ The prevalence of RLS in the general population has been reported to be between $5 \%$ and $10 \%$, but it has been under-recognized. ${ }^{164}$ RLS and its associated condition PLM may increase the risk for cardiovascular and cerebrovascular diseases. ${ }^{230}$ Several studies showed that RLS might be a prognostic factor for stroke, although others obtained conflicting results (Table 3). ${ }^{230-234}$ In a large prospective cohort study, RLS tended to be associated with an elevated risk of total and cardiovascular mortality, and this association between RLS and mortality increased in women with a longer duration of RLS diagnosis. ${ }^{235,236}$ However, two meta-analyses assessing RLS as a risk factor for incident cardiovascular events and all-cause mortality were inconclusive. ${ }^{163,164}$ More severe, longer duration exposures, and secondary forms of RLS were associated with increased risk for stroke. ${ }^{164,230,237}$

Sympathetic overactivity, metabolic dysregulation, inflammation, oxidative stress, peripheral hypoxia, and hypothalamicpituitary-adrenal activation have been proposed as possible linking mechanisms between PLM/RLS and cardiovascular diseases. ${ }^{238}$ Repeated nocturnal fluctuations in heart rate and blood pressure that are associated with PLM and related microarousals cause daytime hypertension, subsequently increasing the risk for cerebrovascular diseases. ${ }^{227,228}$ In a prospective study of 3,116 elderly men, PLM increased atrial fibrillation risk in age-dependent manner. ${ }^{239}$

\section{Circadian rhythm disorders and stroke}

Circadian rhythms are endogenous biological rhythms with near-24-hour periodicity. The internal near-24-hour circadian pacemaker is entrained to the 24-hour light-dark cycle by exogenous cues (primarily light/dark cues, but also eating, and to lesser degrees exercise and social interactions). ${ }^{216}$ Shift workers 
are vulnerable to disruption of normal circadian rhythms. Shift work sleep disorder is characterized by complaints of excessive sleepiness or insomnia that occur when work hours overlap with the usual sleep time. Night shift work is associated with significant interference with the endogenous nocturnal blood pressure decline, resulting in abnormally elevated blood pressure during the shift that persists into the following day. ${ }^{57}$ Shift workers are at risk for obesity, hypertension, diabetes, cardiovascular disease, and overall mortality. ${ }^{240-243}$ In a cohort study of 80,108 nurses, rotating night shift work was associated with a $4 \%$ increased risk of ischemic stroke for every 5 years of exposure, after adjusting for standard vascular risk factors. ${ }^{58} \mathrm{~A}$ recent systematic meta-analysis demonstrated that shift work was associated with ischemic stroke (RR, 1.05; 95\% Cl, 1.01 to 1.09), although the original studies showed mixed results. ${ }^{244}$ Further studies should attempt to clarify the relationship between circadian rhythm disorders (including shift work sleep disorder) and stroke risk, as shift work is common and likely to increase.

\section{Conclusions}

Sleep disorders are highly prevalent in patients at risk for stroke, and may be modifiable risk factors for stroke. OSA increases the risk of stroke independently, but the reported lack of therapeutic effectiveness of CPAP for stroke prevention and cardiovascular protection should be cautiously interpreted. New clinical trials with improved therapeutic precision are necessary. Short or long sleep duration, and insomnia with objective short sleep duration, could be risk factors for stroke and mortality. Sleep-related movement disorders, including PLMS and RLS, are also potential risk factors for stroke. The overall findings suggest that systematic screening and proper management of sleep disturbances can substantially contribute to stroke risk modification at the population level.

\section{Disclosure}

Robert J. Thomas is co-inventor and patent holder of the ECGderived sleep spectrogram, which may be used to phenotype sleep quality and central/complex sleep apnea. The technology is licensed by Beth Israel Deaconess Medical Center to MyCardio, LLC. He is also co-inventor and patent holder of the Positive Airway Pressure Gas Modulator, being developed for treatment of central/complex sleep apnea. He is a consultant in software development for DeVilbiss. The other authors have no financial conflicts of interest.

\section{References}

1. Lozano R, Naghavi M, Foreman K, Lim S, Shibuya K, Aboyans $V$, et al. Global and regional mortality from 235 causes of death for 20 age groups in 1990 and 2010: a systematic analysis for the Global Burden of Disease Study 2010. Lancet 2012;380:2095-2128.

2. Feigin $\mathrm{VL}$, Forouzanfar $M H_{1}$, Krishnamurthi $\mathrm{R}$, Mensah $\mathrm{GA}$, Connor M, Bennett DA, et al. Global and regional burden of stroke during 1990-2010: findings from the Global Burden of Disease Study 2010. Lancet 2014;383:245-254.

3. Koton $S$, Schneider AL, Rosamond WD, Shahar E, Sang $Y$, Gottesman $\mathrm{RF}$, et al. Stroke incidence and mortality trends in US communities, 1987 to 2011. JAMA 2014;312:259-268.

4. Thrift AG, Howard G, Cadilhac DA, Howard VJ, Rothwell PM,

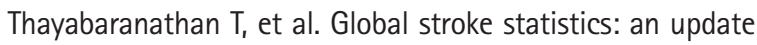
of mortality data from countries using a broad code of "cerebrovascular diseases". Int J Stroke 2017;12:796-801.

5. Hong KS, Bang OY, Kang DW, Yu KH, Bae HJ, Lee JS, et al. Stroke statistics in Korea: part I. Epidemiology and risk factors: a report from the Korean Stroke Society and Clinical Research Center for Stroke. J Stroke 2013;15:2-20.

6. Feigin $V L$, Roth $G A$, Naghavi $M$, Parmar $P$, Krishnamurthi $R$, Chugh $S$, et al. Global burden of stroke and risk factors in 188 countries, during 1990-2013: a systematic analysis for the Global Burden of Disease Study 2013. Lancet Neurol 2016;15:913-924.

7. O'Donnell MJ, Xavier D, Liu L, Zhang H, Chin SL, Rao-Melacini $P$, et al. Risk factors for ischaemic and intracerebral haemorrhagic stroke in 22 countries (the INTERSTROKE study): a case-control study. Lancet 2010;376:112-123.

8. Béjot $Y$, Daubail B, Jacquin A, Durier J, Osseby GV, Rouaud $O$, et al. Trends in the incidence of ischaemic stroke in young adults between 1985 and 2011: the Dijon Stroke Registry. J Neurol Neurosurg Psychiatry 2014;85:509-513.

9. Somers VK, White DP, Amin R, Abraham WT, Costa F, Culebras $A$, et al. Sleep apnea and cardiovascular disease: an American Heart Association/American College of Cardiology Foundation Scientific Statement from the American Heart Association Council for High Blood Pressure Research Professional Education Committee, Council on Clinical Cardiology, Stroke Council, and Council on Cardiovascular Nursing. J Am Coll Cardiol 2008;52:686-717.

10. Cappuccio FP, Cooper D, D'Elia L, Strazzullo P, Miller MA. Sleep duration predicts cardiovascular outcomes: a systematic review and meta-analysis of prospective studies. Eur Heart J 2011;32:1484-1492.

11. Vgontzas AN, Fernandez-Mendoza J, Liao D, Bixler EO. In- 
somnia with objective short sleep duration: the most biologically severe phenotype of the disorder. Sleep Med Rev 2013;17:241-254.

12. Reutrakul S, Mokhlesi B. Obstructive sleep apnea and diabetes: a state of the art review. Chest 2017;152:1070-1086.

13. Winkelman JW, Blackwell T, Stone $K$, Ancoli-Israel $S$, Redline S. Associations of incident cardiovascular events with restless legs syndrome and periodic leg movements of sleep in older men, for the outcomes of Sleep Disorders in Older Men Study (MrOS Sleep Study). Sleep 2017;40:zsx023.

14. Anothaisintawee $T$, Reutrakul $S$, Van Cauter $E_{1}$ Thakkinstian A. Sleep disturbances compared to traditional risk factors for diabetes development: systematic review and meta-analysis. Sleep Med Rev 2016;30:11-24.

15. Knutson $\mathrm{KL}$, Van Cauter E. Associations between sleep loss and increased risk of obesity and diabetes. Ann N Y Acad Sci 2008;1129:287-304.

16. Ford ES, Cunningham TJ, Croft JB. Trends in self-reported sleep duration among us adults from 1985 to 2012. Sleep 2015;38:829-832.

17. Yetish G, Kaplan H, Gurven M, Wood B, Pontzer H, Manger $\mathrm{PR}$, et al. Natural sleep and its seasonal variations in three pre-industrial societies. Curr Biol 2015;25:2862-2868.

18. Saper CB, Fuller PM. Wake-sleep circuitry: an overview. Curr Opin Neurobiol 2017;44:186-192.

19. Verrier RL, Harper RM. Cardiovascular physiology: central and autonomic regulation. In: Kryger MH, Roth $\mathrm{T}_{1}$ Dement WC. Principles and Practice of Sleep Medicine. 5th ed. St. Louis, MO: Elsevier Saunders, 2011;215-225.

20. O'Brien E. Dipping comes of age: the importance of nocturnal blood pressure. Hypertension 2009;53:446-447.

21. Javaheri S, Redline S. Sleep, slow-wave sleep, and blood pressure. Curr Hypertens Rep 2012;14:442-448.

22. Redline $S$, Kirchner HL, Quan SF, Gottlieb DJ, Kapur V, Newman $A$. The effects of age, sex, ethnicity, and sleep-disordered breathing on sleep architecture. Arch Intern Med 2004;164:406-418.

23. Mancia G. Autonomic modulation of the cardiovascular system during sleep. N Engl J Med 1993;328:347-349.

24. Somers VK, Dyken ME, Mark AL, Abboud FM. Sympatheticnerve activity during sleep in normal subjects. $N$ Engl J Med 1993;328:303-307.

25. Halász $P$, Terzano M, Parrino $L$, Bódizs $R$. The nature of arousal in sleep. J Sleep Res 2004;13:1-23.

26. Carrington MJ, Trinder J. Blood pressure and heart rate during continuous experimental sleep fragmentation in healthy adults. Sleep 2008;31:1701-1712.

27. Wu Y, Huang R, Zhong $X$, Xiao Y. Cardiovascular consequenc- es of repetitive arousals over the entire sleep duration. Biomed Res Int 2017;2017:4213861.

28. Hermida RC, Ayala DE, Smolensky MH, Fernández JR, Mojón A, Portaluppi F. Sleep-time blood pressure: unique sensitive prognostic marker of vascular risk and therapeutic target for prevention. Sleep Med Rev 2017;33:17-27.

29. Smolensky MH, Hermida RC, Ayala DE, Portaluppi F. Bedtime hypertension chronotherapy: concepts and patient outcomes. Curr Pharm Des 2015;21:773-790.

30. Smolensky MH, Hermida RC, Portaluppi F. Circadian mechanisms of 24-hour blood pressure regulation and patterning. Sleep Med Rev 2017;33:4-16.

31. Bankir L, Bochud M, Maillard M, Bovet $P$, Gabriel $A$, Burnier $M$. Nighttime blood pressure and nocturnal dipping are associated with daytime urinary sodium excretion in African subjects. Hypertension 2008;51:891-898.

32. Birkenhäger $A M$, van den Meiracker AH. Causes and consequences of a non-dipping blood pressure profile. Neth J Med 2007;65:127-131.

33. Bouhanick B, Bongard V, Amar J, Bousquel S, Chamontin B. Prognostic value of nocturnal blood pressure and reverse-dipping status on the occurrence of cardiovascular events in hypertensive diabetic patients. Diabetes Metab 2008;34:560567.

34. Hassan MO, Jaju D, Albarwani S, Al-Yahyaee S, Al-Hadabi S, Lopez-Alvarenga JC, et al. Non-dipping blood pressure in the metabolic syndrome among Arabs of the Oman family study. Obesity (Silver Spring) 2007;15:2445-2453.

35. Mellman TA, Brown DD, Jenifer ES, Hipolito MM, Randall OS. Posttraumatic stress disorder and nocturnal blood pressure dipping in young adult African Americans. Psychosom Med 2009;71:627-630.

36. Kastarinen $H$, Vasunta RL, Ukkola O, Kesäniemi YA. Glomerular filtration rate is related to dipping pattern in ambulatory blood pressure monitoring: a cross-sectional populationbased study. J Hum Hypertens 2010;24:247-253.

37. Kario K, Shimada K, Pickering TG. Abnormal nocturnal blood pressure falls in elderly hypertension: clinical significance and determinants. J Cardiovasc Pharmacol 2003;41 Suppl 1:S61-S66.

38. Loredo JS, Ancoli-Israel S, Dimsdale JE. Sleep quality and blood pressure dipping in obstructive sleep apnea. Am J Hypertens 2001;14:887-892.

39. Loredo JS, Nelesen R, Ancoli-Israel S, Dimsdale JE. Sleep quality and blood pressure dipping in normal adults. Sleep 2004;27:1097-1103.

40. Matthews KA, Kamarck TW, Hall MH, Strollo PJ, Owens JF, Buysse DJ, et al. Blood pressure dipping and sleep distur- 
bance in African-American and Caucasian men and women. Am J Hypertens 2008;21:826-831.

41. Routledge FS, McFetridge-Durdle JA, Dean CR; Canadian Hypertension Society. Night-time blood pressure patterns and target organ damage: a review. Can J Cardiol 2007;23:132-138.

42. Bastos JM, Bertoquini S, Silva JA, Polónia J. Relationship between ambulatory blood pressure monitoring values and future occurrence of ischemic cerebrovascular and coronary events in hypertensive patients. Rev Port Cardiol 2006;25:305-316.

43. Yamamoto Y, Akiguchi I, Oiwa K, Hayashi M, Ohara T, Ozasa $K$. The relationship between 24-hour blood pressure readings, subcortical ischemic lesions and vascular dementia. Cerebrovasc Dis 2005;19:302-308.

44. Hajjar I, Zhao P, Alsop D, Abduljalil A, Selim M, Novak P, et al. Association of blood pressure elevation and nocturnal dipping with brain atrophy, perfusion and functional measures in stroke and nonstroke individuals. Am J Hypertens 2010;23:17-23.

45. Hajjar I, Selim M, Novak P, Novak V. The relationship between nighttime dipping in blood pressure and cerebral hemodynamics in nonstroke patients. J Clin Hypertens (Greenwich) 2007;9:929-936.

46. Redline S, Foody J. Sleep disturbances: time to join the top 10 potentially modifiable cardiovascular risk factors? Circulation 2011;124:2049-2051.

47. Yaggi HK, Concato J, Kernan WN, Lichtman JH, Brass LM, Mohsenin V. Obstructive sleep apnea as a risk factor for stroke and death. N Engl J Med 2005;353:2034-2041.

48. Arzt M, Young T, Finn L, Skatrud JB, Bradley TD. Association of sleep-disordered breathing and the occurrence of stroke. Am J Respir Crit Care Med 2005;172:1447-1451.

49. Redline S, Yenokyan G, Gottlieb DJ, Shahar E, O'Connor GT,

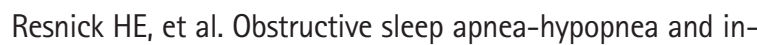
cident stroke: the sleep heart health study. Am J Respir Crit Care Med 2010;182:269-277.

50. Loke YK, Brown JW, Kwok CS, Niruban A, Myint PK. Association of obstructive sleep apnea with risk of serious cardiovascular events: a systematic review and meta-analysis. Circ Cardiovasc Qual Outcomes 2012;5:720-728.

51. Leng Y, Cappuccio FP, Wainwright NW, Surtees PG, Luben $R$,

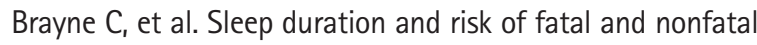
stroke: a prospective study and meta-analysis. Neurology 2015;84:1072-1079.

52. He $Q$, Sun $H$, Wu X, Zhang P, Dai H, Ai C, et al. Sleep duration and risk of stroke: a dose-response meta-analysis of prospective cohort studies. Sleep Med 2017;32:66-74.

53. Wu MP, Lin HJ, Weng SF, Ho CH, Wang JJ, Hsu YW. Insomnia subtypes and the subsequent risks of stroke: report from a nationally representative cohort. Stroke 2014;45:1349-1354.
54. Fernandez-Mendoza J, Baker JH, Vgontzas AN, Gaines J, Liao D, Bixler EO. Insomnia symptoms with objective short sleep duration are associated with systemic inflammation in adolescents. Brain Behav Immun 2017;61:110-116.

55. Koo BB, Blackwell T, Ancoli-Israel S, Stone KL, Stefanick ML, Redline $S$, et al. Association of incident cardiovascular disease with periodic limb movements during sleep in older men: outcomes of sleep disorders in older men (MrOS) study. Circulation 2011;124:1223-1231.

56. Ferri R, Zucconi M. Heart rate and spectral EEG changes accompanying periodic and isolated leg movements during sleep. Sleep 2008;31:16-17.

57. Lo SH, Lin LY, Hwang JS, Chang YY, Liau CS, Wang JD. Working the night shift causes increased vascular stress and delayed recovery in young women. Chronobiol Int 2010;27:1454-1468.

58. Brown DL, Feskanich D, Sanchez BN, Rexrode KM, Schernhammer ES, Lisabeth LD. Rotating night shift work and the risk of ischemic stroke. Am J Epidemiol 2009;169:1370-1377.

59. Cowie MR, Woehrle $H$, Wegscheider K, Angermann C, d'Ortho

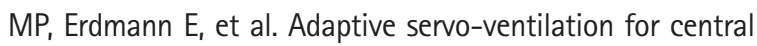
sleep apnea in systolic heart failure. N Engl J Med 2015;373: 1095-1105.

60. McEvoy RD, Antic NA, Heeley E, Luo Y, Ou Q, Zhang X, et al. CPAP for prevention of cardiovascular events in obstructive sleep apnea. N Engl J Med 2016;375:919-931.

61. Peker Y, Glantz H, Eulenburg C, Wegscheider K, Herlitz J, Thunström E. Effect of positive airway pressure on cardiovascular outcomes in coronary artery disease patients with nonsleepy obstructive sleep apnea. The RICCADSA randomized controlled trial. Am J Respir Crit Care Med 2016;194:613620.

62. Young T, Palta M, Dempsey J, Skatrud J, Weber S, Badr S. The occurrence of sleep-disordered breathing among middleaged adults. N Engl J Med 1993;328:1230-1235.

63. Durán J, Esnaola S, Rubio R, Iztueta A. Obstructive sleep apnea-hypopnea and related clinical features in a populationbased sample of subjects aged 30 to $70 \mathrm{yr}$. Am J Respir Crit Care Med 2001;163:685-689.

64. Bixler EO, Vgontzas AN, Lin HM, Ten Have T, Rein J, Vela-Bueno

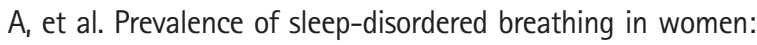
effects of gender. Am J Respir Crit Care Med 2001;163:608613.

65. Kim J, In K, Kim J, You S, Kang K, Shim J, et al. Prevalence of sleep-disordered breathing in middle-aged Korean men and women. Am J Respir Crit Care Med 2004;170:1108-1113.

66. Peppard PE, Young T, Barnet JH, Palta M, Hagen EW, Hla KM. Increased prevalence of sleep-disordered breathing in adults. Am J Epidemiol 2013;177:1006-1014. 
67. Heinzer $R$, Vat $S$, Marques-Vidal P, Marti-Soler $H$, Andries $D$, Tobback $N$, et al. Prevalence of sleep-disordered breathing in the general population: the HypnoLaus study. Lancet Respir Med 2015;3:310-318.

68. Senaratna CV, Perret $J \mathrm{~L}$, Lodge CJ, Lowe AJ, Campbell BE, Matheson $\mathrm{MC}$, et al. Prevalence of obstructive sleep apnea in the general population: a systematic review. Sleep Med Rev 2017;34:70-81.

69. Guilleminault C, Tilkian A, Dement WC. The sleep apnea syndromes. Annu Rev Med 1976;27:465-484.

70. Bassetti CL, Hermann DM. Sleep and stroke. Handb Clin Neurol 2011;99:1051-1072.

71. Sanfilippo-Cohn B, Lai S, Zhan G, Fenik P, Pratico D, Mazza E, et al. Sex differences in susceptibility to oxidative injury and sleepiness from intermittent hypoxia. Sleep 2006;29:152159.

72. Veasey SC, Davis CW, Fenik P, Zhan G, Hsu YJ, Pratico D, et al. Long-term intermittent hypoxia in mice: protracted hypersomnolence with oxidative injury to sleep-wake brain regions. Sleep 2004;27:194-201.

73. Zhan G, Fenik P, Pratico D, Veasey SC. Inducible nitric oxide synthase in long-term intermittent hypoxia: hypersomnolence and brain injury. Am J Respir Crit Care Med 2005;171:14141420.

74. Morrell MJ. Residual sleepiness in patients with optimally treated sleep apnea: a case for hypoxia-induced oxidative brain injury. Sleep 2004;27:186-187.

75. Gozal E, Gozal D, Pierce WM, Thongboonkerd V, Scherzer JA, Sachleben LR Jr, et al. Proteomic analysis of CA1 and CA3 regions of rat hippocampus and differential susceptibility to intermittent hypoxia. J Neurochem 2002;83:331-345.

76. Hambrecht VS, Vlisides PE, Row BW, Gozal D, Baghdoyan HA, Lydic R. Hypoxia modulates cholinergic but not opioid activation of $\mathrm{G}$ proteins in rat hippocampus. Hippocampus 2007;17:934-942.

77. Row BW, Kheirandish L, Cheng Y, Rowell PP, Gozal D. Impaired spatial working memory and altered choline acetyltransferase (CHAT) immunoreactivity and nicotinic receptor binding in rats exposed to intermittent hypoxia during sleep. Behav Brain Res 2007;177:308-314.

78. Zhu Y, Fenik P, Zhan G, Mazza E, Kelz M, Aston-Jones G, et al. Selective loss of catecholaminergic wake active neurons in a murine sleep apnea model. J Neurosci 2007;27:1006010071.

79. Row BW, Liu R, Xu W, Kheirandish L, Gozal D. Intermittent hypoxia is associated with oxidative stress and spatial learning deficits in the rat. Am J Respir Crit Care Med 2003;167:15481553.
80. Xu W, Chi L, Row BW, Xu R, Ke Y, Xu B, et al. Increased oxidative stress is associated with chronic intermittent hypoxiamediated brain cortical neuronal cell apoptosis in a mouse model of sleep apnea. Neuroscience 2004;126:313-323.

81. Li RC, Row BW, Kheirandish L, Brittian KR, Gozal E, Guo SZ, et al. Nitric oxide synthase and intermittent hypoxia-induced spatial learning deficits in the rat. Neurobiol Dis 2004;17:4453.

82. Lavie L. Oxidative stress in obstructive sleep apnea and intermittent hypoxia: revisited. The bad ugly and good: implications to the heart and brain. Sleep Med Rev 2015;20:27-45.

83. Minoguchi K, Yokoe T, Tazaki T, Minoguchi H, Oda N, Tanaka A, et al. Silent brain infarction and platelet activation in obstructive sleep apnea. Am J Respir Crit Care Med 2007;175:612-617.

84. Kim H, Yun CH, Thomas RJ, Lee SH, Seo HS, Cho ER, et al. Obstructive sleep apnea as a risk factor for cerebral white matter change in a middle-aged and older general population. Sleep 2013;36:709B-715B.

85. Koo DL, Kim JY, Lim JS, Kwon HM, Nam H. Cerebral microbleeds on MRI in patients with obstructive sleep apnea. J Clin Sleep Med 2017;13:65-72.

86. Song TJ, Park JH, Choi KH, Chang Y, Moon J, Kim JH, et al. Moderate-to-severe obstructive sleep apnea is associated with cerebral small vessel disease. Sleep Med 2017;30:3642.

87. Song TJ, Park JH, Choi KH, Kim JH, Choi Y, Chang Y, et al. Is obstructive sleep apnea associated with the presence of intracranial cerebral atherosclerosis? Sleep Breath 2017;21:639-646.

88. Yun $\mathrm{CH}_{1}$ Jung $\mathrm{KH}, \mathrm{Chu} \mathrm{K}_{1} \mathrm{Kim} \mathrm{SH}_{1}$ Ji KH, Park HK, et al. Increased circulating endothelial microparticles and carotid atherosclerosis in obstructive sleep apnea. J Clin Neurol 2010;6:89-98.

89. Kim J, Mohler ER 3rd, Keenan BT, Maislin D, Arnardottir ES, Gis-

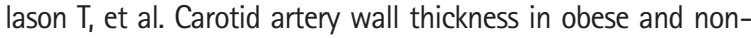
obese adults with obstructive sleep apnea before and following positive airway pressure treatment. Sleep 2017;40:zsx126.

90. Nieto FJ, Young TB, Lind BK, Shahar E, Samet JM, Redline $S$, et al. Association of sleep-disordered breathing, sleep apnea, and hypertension in a large community-based study. Sleep Heart Health Study. JAMA 2000;283:1829-1836.

91. Peppard PE, Young T, Palta M, Skatrud J. Prospective study of the association between sleep-disordered breathing and hypertension. N Engl J Med 2000;342:1378-1384.

92. Williams SK, Ravenell J, Jean-Louis G, Zizi F, Underberg JA, McFarlane SI, et al. Resistant hypertension and sleep apnea: pathophysiologic insights and strategic management. Curr Diab Rep 2011;11:64-69.

93. Becker HF, Jerrentrup A, Ploch T, Grote L, Penzel T, Sullivan 


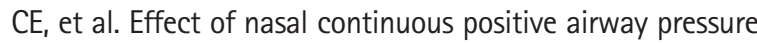
treatment on blood pressure in patients with obstructive sleep apnea. Circulation 2003;107:68-73.

94. Pepperell JC, Ramdassingh-Dow S, Crosthwaite N, Mullins R, Jenkinson C, Stradling JR, et al. Ambulatory blood pressure after therapeutic and subtherapeutic nasal continuous positive airway pressure for obstructive sleep apnoea: a randomised parallel trial. Lancet 2002;359:204-210.

95. Martínez-García MA, Capote $F$, Campos-Rodríguez F, Lloberes $P$, Díaz de Atauri MJ, Somoza M, et al. Effect of CPAP on blood pressure in patients with obstructive sleep apnea and resistant hypertension: the HIPARCO randomized clinical trial. JAMA 2013;310:2407-2415.

96. Rasche K, Keller T, Tautz B, Hader C, Hergenc G, Antosiewicz $J$, et al. Obstructive sleep apnea and type 2 diabetes. Eur J Med Res 2010;15 Suppl 2:152-156.

97. Martínez-Cerón E, Barquiel B, Bezos AM, Casitas R, Galera R, García-Benito $C$, et al. Effect of continuous positive airway pressure on glycemic control in patients with obstructive sleep apnea and type 2 diabetes. a randomized clinical trial. Am J Respir Crit Care Med 2016;194:476-485.

98. Mokhlesi B, Grimaldi D, Beccuti G, Abraham V, Whitmore H, Delebecque $F$, et al. Effect of one week of 8-hour nightly continuous positive airway pressure treatment of obstructive sleep apnea on glycemic control in type 2 diabetes: a proofof-concept study. Am J Respir Crit Care Med 2016;194:516519.

99. Yamashita $T$, Murakawa $Y$, Sezaki $K$, Inoue M, Hayami N, Shuzui $Y$, et al. Circadian variation of paroxysmal atrial fibrillation. Circulation 1997;96:1537-1541.

100. Mehra R, Benjamin EJ, Shahar E, Gottlieb DJ, Nawabit R, Kirchner $\mathrm{HL}$, et al. Association of nocturnal arrhythmias with sleep-disordered breathing: the Sleep Heart Health Study. Am J Respir Crit Care Med 2006;173:910-916.

101. Gami AS, Hodge DO, Herges RM, Olson EJ, Nykodym J, Kara T, et al. Obstructive sleep apnea, obesity, and the risk of incident atrial fibrillation. J Am Coll Cardiol 2007;49:565-571.

102. Cadby G, McArdle N, Briffa T, Hillman DR, Simpson L, Knuiman $M$, et al. Severity of OSA is an independent predictor of incident atrial fibrillation hospitalization in a large sleepclinic cohort. Chest 2015;148:945-952.

103. Yazdan-Ashoori P, Baranchuk A. Obstructive sleep apnea may increase the risk of stroke in AF patients: refining the CHADS2 score. Int J Cardiol 2011;146:131-133.

104. Szymanski FM, Filipiak KJ, Platek AE, Hrynkiewicz-Szymanska A, Karpinski G, Opolski G. Assessment of CHADS2 and CHA 2DS 2-VASc scores in obstructive sleep apnea patients with atrial fibrillation. Sleep Breath 2015;19:531-537.
105. Guilleminault C, Connolly SJ, Winkle RA. Cardiac arrhythmia and conduction disturbances during sleep in 400 patients with sleep apnea syndrome. Am J Cardiol 1983;52:490-494.

106. Kanagala R, Murali NS, Friedman PA, Ammash NM, Gersh BJ, Ballman KV, et al. Obstructive sleep apnea and the recurrence of atrial fibrillation. Circulation 2003;107:2589-2594.

107. McNicholas WT. Obstructive sleep apnea and inflammation. Prog Cardiovasc Dis 2009;51:392-399.

108. Mehra R, Storfer-Isser A, Kirchner HL, Johnson N, Jenny $N_{\text {, }}$ Tracy RP, et al. Soluble interleukin 6 receptor: a novel marker of moderate to severe sleep-related breathing disorder. Arch Intern Med 2006;166:1725-1731.

109. Thomopoulos C, Tsioufis C, Dimitriadis K, Tsiachris D, Tousoulis $D$, Manolis A, et al. Obstructive sleep apnoea syndrome is associated with enhanced sub-clinical inflammation and asymmetric dimethyl-arginine levels in hypertensives. J Hum Hypertens 2009;23:65-67.

110. Yue HJ, Mills PJ, Ancoli-Israel S, Loredo JS, Ziegler MG, Dimsdale JE. The roles of TNF-alpha and the soluble TNF receptor I on sleep architecture in OSA. Sleep Breath 2009;13:263-269.

111. Lurie A. Endothelial dysfunction in adults with obstructive sleep apnea. Adv Cardiol 2011;46:139-170.

112. Wang J, Yu W, Gao M, Zhang F, Gu C, Yu Y, et al. Impact of obstructive sleep apnea syndrome on endothelial function, arterial stiffening, and serum inflammatory markers: an updated meta-analysis and metaregression of 18 studies. J Am Heart Assoc 2015;4:e002454.

113. Wessendorf TE, Thilmann AF, Wang YM, Schreiber A, Konietzko $\mathrm{N}$, Teschler $\mathrm{H}$. Fibrinogen levels and obstructive sleep apnea in ischemic stroke. Am J Respir Crit Care Med 2000;162:20392042.

114. von Känel $R$, Dimsdale JE. Hemostatic alterations in patients with obstructive sleep apnea and the implications for cardiovascular disease. Chest 2003;124:1956-1967.

115. Saygin M, Ozturk O, Ozguner MF, Akkaya A, Varol E. Hematological parameters as predictors of cardiovascular disease in obstructive sleep apnea syndrome patients. Angiology 2016; 67:461-470.

116. Diomedi M, Placidi F, Cupini LM, Bernardi G, Silvestrini M. Cerebral hemodynamic changes in sleep apnea syndrome and effect of continuous positive airway pressure treatment. Neurology 1998;51:1051-1056.

117. Pizza F, Biallas M, Wolf M, Werth E, Bassetti CL. Nocturnal cerebral hemodynamics in snorers and in patients with obstructive sleep apnea: a near-infrared spectroscopy study. Sleep 2010;33:205-210.

118. Prilipko 0, Huynh N, Thomason ME, Kushida CA, Guilleminault $\mathrm{C}$. An fMRI study of cerebrovascular reactivity and 
perfusion in obstructive sleep apnea patients before and after CPAP treatment. Sleep Med 2014;15:892-898.

119. Bassetti C, Aldrich MS, Chervin RD, Quint D. Sleep apnea in patients with transient ischemic attack and stroke: a prospective study of 59 patients. Neurology 1996;47:1167-1173.

120. Parra O, Arboix A, Bechich S, García-Eroles L, Montserrat JM, López JA, et al. Time course of sleep-related breathing disorders in first-ever stroke or transient ischemic attack. Am J Respir Crit Care Med 2000;161:375-380.

121. Turkington PM, Bamford J, Wanklyn P, Elliott MW. Prevalence and predictors of upper airway obstruction in the first 24 hours after acute stroke. Stroke 2002;33:2037-2042.

122. Ahn SH, Kim JH, Kim DU, Choo IS, Lee HJ, Kim HW. Interaction between sleep-disordered breathing and acute ischemic stroke. J Clin Neurol 2013;9:9-13.

123. Shahar E, Whitney CW, Redline S, Lee ET, Newman AB, Nieto $\mathrm{FJ}$, et al. Sleep-disordered breathing and cardiovascular disease: cross-sectional results of the Sleep Heart Health Study. Am J Respir Crit Care Med 2001;163:19-25.

124. Peker Y, Hedner J, Norum J, Kraiczi H, Carlson J. Increased incidence of cardiovascular disease in middle-aged men with obstructive sleep apnea: a 7-year follow-up. Am J Respir Crit Care Med 2002;166:159-165.

125. Marin JM, Carrizo SJ, Vicente E, Agusti AG. Long-term cardiovascular outcomes in men with obstructive sleep apnoea-hypopnoea with or without treatment with continuous positive airway pressure: an observational study. Lancet 2005;365: 1046-1053.

126. Munoz R, Duran-Cantolla J, Martínez-Vila E, Gallego J, Rubio $R$, Aizpuru $F$, et al. Severe sleep apnea and risk of ischemic stroke in the elderly. Stroke 2006;37:2317-2321.

127. Young T, Finn L, Peppard PE, Szklo-Coxe M, Austin D, Nieto FJ, et al. Sleep disordered breathing and mortality: eighteen-year follow-up of the Wisconsin sleep cohort. Sleep 2008;31:10711078.

128. Yeboah J, Redline S, Johnson C, Tracy R, Ouyang P, Blumenthal RS, et al. Association between sleep apnea, snoring, incident cardiovascular events and all-cause mortality in an adult population: MESA. Atherosclerosis 2011;219:963-968.

129. Redline S, Schluchter MD, Larkin EK, Tishler PV. Predictors of longitudinal change in sleep-disordered breathing in a nonclinic population. Sleep 2003;26:703-709.

130. Dong JY, Zhang YH, Oin LQ. Obstructive sleep apnea and cardiovascular risk: meta-analysis of prospective cohort studies. Atherosclerosis 2013;229:489-495.

131. Patrick AR, Shrank WH, Glynn RJ, Solomon DH, Dormuth $C R$, Avorn J, et al. The association between statin use and outcomes potentially attributable to an unhealthy lifestyle in older adults. Value Health 2011;14:513-520.

132. Simpson SH, Eurich DT, Majumdar SR, Padwal RS, Tsuyuki RT, Varney $J$, et al. A meta-analysis of the association between adherence to drug therapy and mortality. BMJ 2006;333:15.

133. Drager LF, McEvoy RD, Barbe F, Lorenzi-Filho G, Redline S; INCOSACT Initiative (International Collaboration of Sleep Apnea Cardiovascular Trialists). Sleep apnea and cardiovascular disease: lessons from recent trials and need for team science. Circulation 2017;136:1840-1850.

134. Peker $Y$, Glantz $H$, Thunström $E$, Kallryd A, Herlitz J, Ejdebäck $J$. Rationale and design of the Randomized Intervention with CPAP in Coronary Artery Disease and Sleep Apnoea: RICCADSA trial. Scand Cardiovasc J 2009;43:24-31.

135. Antic NA, Heeley E, Anderson CS, Luo Y, Wang J, Neal B, et al. The Sleep Apnea cardioVascular Endpoints (SAVE) Trial: rationale, ethics, design, and progress. Sleep 2015;38:1247-1257.

136. Mokhlesi B, Ayas NT. Cardiovascular events in obstructive sleep apnea: can CPAP therapy SAVE lives? N Engl J Med 2016;375:994-996.

137. Parthasarathy S. The positive and negative about positive airway pressure therapy. Am J Respir Crit Care Med 2016;194: 535-537.

138. Li Y, Vgontzas AN, Fernandez-Mendoza J, Kritikou I, Basta M, Pejovic $S$, et al. Objective, but not subjective, sleepiness is associated with inflammation in sleep apnea. Sleep 2017;40: zsw033.

139. Barceló $A$, Barbé $F$, de la Peña $M$, Martinez $P$, Soriano JB, Piérola J, et al. Insulin resistance and daytime sleepiness in patients with sleep apnoea. Thorax 2008;63:946-950.

140. Robinson GV, Langford BA, Smith DM, Stradling JR. Predictors of blood pressure fall with continuous positive airway pressure (CPAP) treatment of obstructive sleep apnoea (OSA). Thorax 2008;63:855-859.

141. Barbé F, Mayoralas LR, Duran J, Masa JF, Maimó A, Montserrat JM, et al. Treatment with continuous positive airway pressure is not effective in patients with sleep apnea but no daytime sleepiness. a randomized, controlled trial. Ann Intern Med 2001;134:1015-1023.

142. Robinson GV, Smith DM, Langford BA, Davies RJ, Stradling $J R$. Continuous positive airway pressure does not reduce blood pressure in nonsleepy hypertensive OSA patients. Eur Respir J 2006;27:1229-1235.

143. Craig SE, Kohler M, Nicoll D, Bratton DJ, Nunn A, Davies R, et al. Continuous positive airway pressure improves sleepiness but not calculated vascular risk in patients with minimally symptomatic obstructive sleep apnoea: the MOSAIC randomised controlled trial. Thorax 2012;67:1090-1096.

144. Barbé F, Durán-Cantolla J, Sánchez-de-la-Torre M, Martínez- 
Alonso M, Carmona C, Barceló A, et al. Effect of continuous positive airway pressure on the incidence of hypertension and cardiovascular events in nonsleepy patients with obstructive sleep apnea: a randomized controlled trial. JAMA 2012;307:2161-2168.

145. Bratton DJ, Stradling JR, Barbé F, Kohler M. Effect of CPAP on blood pressure in patients with minimally symptomatic obstructive sleep apnoea: a meta-analysis using individual patient data from four randomised controlled trials. Thorax 2014;69:1128-1135.

146. Campos-Rodriguez $F$, Peña-Griñan N, Reyes-Nuñez N, De la Cruz-Moron I, Perez-Ronchel J, De la Vega-Gallardo F, et al. Mortality in obstructive sleep apnea-hypopnea patients treated with positive airway pressure. Chest 2005;128:624-633.

147. Barbé $F$, Durán-Cantolla J, Capote $F$, de la Peña $M$, Chiner $E_{1}$ Masa JF, et al. Long-term effect of continuous positive airway pressure in hypertensive patients with sleep apnea. Am J Respir Crit Care Med 2010;181:718-726.

148. Bianchi MT, Alameddine Y, Mojica J. Apnea burden: efficacy versus effectiveness in patients using positive airway pressure. Sleep Med 2014;15:1579-1581.

149. Boyd SB, Upender R, Walters AS, Goodpaster RL, Stanley JJ, Wang $L$, et al. Effective apnea-hypopnea index ("Effective AHI"): a new measure of effectiveness for positive airway pressure therapy. Sleep 2016;39:1961-1972.

150. Thomas RJ, Bianchi MT. Urgent need to improve PAP management: the devil is in two (fixable) details. J Clin Sleep Med 2017;13:657-664.

151. Kohler M, Stoewhas AC, Ayers L, Senn O, Bloch KE, Russi EW, et al. Effects of continuous positive airway pressure therapy withdrawal in patients with obstructive sleep apnea: a randomized controlled trial. Am J Respir Crit Care Med 2011;184: 1192-1199.

152. Young LR, Taxin ZH, Norman RG, Walsleben JA, Rapoport DM, Ayappa I. Response to CPAP withdrawal in patients with mild versus severe obstructive sleep apnea/hypopnea syndrome. Sleep 2013;36:405-412.

153. Mokhlesi B, Finn LA, Hagen EW, Young T, Hla KM, Van Cauter

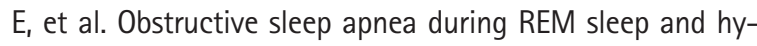
pertension. Results of the Wisconsin Sleep Cohort. Am J Respir Crit Care Med 2014;190:1158-1167.

154. Appleton SL, Vakulin A, Martin SA, Lang CJ, Wittert GA, Taylor $A W$, et al. Hypertension is associated with undiagnosed OSA during rapid eye movement sleep. Chest 2016;150:495505.

155. Mokhlesi B, Hagen EW, Finn LA, Hla KM, Carter JR, Peppard PE. Obstructive sleep apnoea during REM sleep and incident non-dipping of nocturnal blood pressure: a longitudinal analy- sis of the Wisconsin Sleep Cohort. Thorax 2015;70:1062-1069.

156. Chami HA, Gottlieb DJ, Redline S, Punjabi NM. Association between glucose metabolism and sleep-disordered breathing during REM sleep. Am J Respir Crit Care Med 2015;192:11181126.

157. Aurora RN, Crainiceanu C, Gottlieb DJ, Kim JS, Punjabi NM. Obstructive sleep apnea during rapid eye movement sleep and cardiovascular disease. Am J Respir Crit Care Med. 2017 Nov 7 [Epub]. https://doi.org/10.1164/rccm.201706-11120C.

158. Mokhlesi B, Varga AW. Obstructive sleep apnea and cardiovascular disease: REM sleep matters! Am J Respir Crit Care Med. 2017 Nov 15 [Epub]. https://doi.org/10.1164/rccm.2017102147ED.

159. Collop NA, Tracy SL, Kapur V, Mehra R, Kuhlmann D, Fleishman SA, et al. Obstructive sleep apnea devices for out-ofcenter (OOC) testing: technology evaluation. J Clin Sleep Med $2011 ; 7: 531-548$.

160. Malhotra A, Patil S, Sands S, Ayas N. Central sleep apnoea in congestive heart failure. Lancet Respir Med 2015;3:507-508.

161. Magalang UJ, Pack AI. Heart failure and sleep-disordered breathing: the plot thickens. N Engl J Med 2015;373:11661167.

162. Boulos MI, Murray BJ, Muir RT, Gao F, Szilagyi GM, Huroy M, et al. Periodic limb movements and white matter hyperintensities in first-ever minor stroke or high-risk transient ischemic attack. Sleep 2017;40:zsw080.

163. Katsanos AH, Kosmidou M, Konitsiotis S, Tsivgoulis G, Fiolaki $A$, Kyritsis $A P$, et al. Restless legs syndrome and cerebrovascular/cardiovascular events: systematic review and metaanalysis. Acta Neurol Scand 2018;137:142-148.

164. Kendzerska T, Kamra M, Murray BJ, Boulos MI. Incident cardiovascular events and death in individuals with restless legs syndrome or periodic limb movements in sleep: a systematic review. Sleep 2017;40:zsx013.

165. Eckert DJ. Phenotypic approaches to obstructive sleep apnoea: new pathways for targeted therapy. Sleep Med Rev 2018;37:45-59.

166. Javaheri S, Barbe F, Campos-Rodriguez F, Dempsey JA, Khayat $R$, Javaheri $S$, et al. Sleep apnea: types, mechanisms, and clinical cardiovascular consequences. J Am Coll Cardiol 2017;69:841-858.

167. Zinchuk AV, Gentry MJ, Concato J, Yaggi HK. Phenotypes in obstructive sleep apnea: a definition, examples and evolution of approaches. Sleep Med Rev 2017;35:113-123.

168. 168. Edwards BA, Sands SA, Eckert DJ, White DP, Butler JP, Owens $\mathrm{RL}$, et al. Acetazolamide improves loop gain but not the other physiological traits causing obstructive sleep apnoea. J Physio/ 2012;590:1199-1211. 
169. Thomas RJ. Alternative approaches to treatment of Central Sleep Apnea. Sleep Med Clin 2014;9:87-104.

170. Reiter J, Zleik B, Bazalakova M, Mehta P, Thomas RJ. Residual events during use of CPAP: prevalence, predictors, and detection accuracy. J Clin Sleep Med 2016;12:1153-1158.

171. Campos-Rodriguez F, Martinez-Garcia MA, Reyes-Nuñez N, Caballero-Martinez I, Catalan-Serra P, Almeida-Gonzalez CV. Role of sleep apnea and continuous positive airway pressure therapy in the incidence of stroke or coronary heart disease in women. Am J Respir Crit Care Med 2014;189:1544-1550.

172. Chen JC, Brunner RL, Ren H, Wassertheil-Smoller S, Larson JC, Levine DW, et al. Sleep duration and risk of ischemic stroke in postmenopausal women. Stroke 2008;39:3185-3192.

173. Helbig AK, Stöckl D, Heier M, Ladwig KH, Meisinger C. Symptoms of insomnia and sleep duration and their association with incident strokes: findings from the population-based MONICA/ KORA Augsburg Cohort Study. PLoS One 2015;10:e0134480.

174. von Ruesten A, Weikert C, Fietze I, Boeing H. Association of sleep duration with chronic diseases in the European Prospective Investigation into Cancer and Nutrition (EPIC)-Potsdam study. PLoS One 2012;7:e30972.

175. Li W, Wang D, Cao S, Yin X, Gong Y, Gan Y, et al. Sleep duration and risk of stroke events and stroke mortality: a systematic review and meta-analysis of prospective cohort studies. Int J Cardiol 2016;223:870-876.

176. Gangwisch JE, Heymsfield SB, Boden-Albala B, Buijs RM, Kreier F, Pickering TG, et al. Short sleep duration as a risk factor for hypertension: analyses of the first National Health and Nutrition Examination Survey. Hypertension 2006;47:833-839.

177. Gangwisch JE, Malaspina D, Babiss LA, Opler MG, Posner K, Shen $\mathrm{S}$, et al. Short sleep duration as a risk factor for hypercholesterolemia: analyses of the National Longitudinal Study of Adolescent Health. Sleep 2010;33:956-961.

178. Pan A, De Silva DA, Yuan JM, Koh WP. Sleep duration and risk of stroke mortality among Chinese adults: Singapore Chinese health study. Stroke 2014;45:1620-1625.

179. Kim Y, Wilkens LR, Schembre SM, Henderson BE, Kolonel LN, Goodman MT. Insufficient and excessive amounts of sleep increase the risk of premature death from cardiovascular and other diseases: the Multiethnic Cohort Study. Prev Med 2013;57:377-385.

180. Chaput JP, Després JP, Bouchard C, Astrup A, Tremblay A. Sleep duration as a risk factor for the development of type 2 diabetes or impaired glucose tolerance: analyses of the Quebec Family Study. Sleep Med 2009;10:919-924.

181. Kawachi T, Wada K, Nakamura K, Tsuji M, Tamura T, Konishi $K$, et al. Sleep duration and the risk of mortality from stroke in Japan: the Takayama Cohort Study. J Epidemiol 2016;
26:123-130.

182. Qureshi Al, Giles WH, Croft JB, Bliwise DL. Habitual sleep patterns and risk for stroke and coronary heart disease: a 10year follow-up from NHANES I. Neurology 1997;48:904-911.

183. Cai $H$, Shu XO, Xiang YB, Yang G, Li H, Ji BT, et al. Sleep duration and mortality: a prospective study of 113138 middleaged and elderly Chinese men and women. Sleep 2015; 38:529-536.

184. Ge B, Guo X. Short and long sleep durations are both associated with increased risk of stroke: a meta-analysis of observational studies. Int J Stroke 2015;10:177-184.

185. Lockley SW, Skene DJ, Arendt J. Comparison between subjective and actigraphic measurement of sleep and sleep rhythms. J Sleep Res 1999;8:175-183.

186. Signal TL, Gale J, Gander PH. Sleep measurement in flight crew: comparing actigraphic and subjective estimates to polysomnography. Aviat Space Environ Med 2005;76:10581063.

187. Lauderdale DS, Knutson KL, Yan LL, Liu K, Rathouz PJ. Selfreported and measured sleep duration: how similar are they? Epidemiology 2008;19:838-845.

188. Li AM, Lam HS, Chan MH, So HK, Ng SK, Chan IH, et al. Inflammatory cytokines and childhood obstructive sleep apnoea. Ann Acad Med Singapore 2008;37:649-654.

189. Gallicchio L, Kalesan B. Sleep duration and mortality: a systematic review and meta-analysis. J Sleep Res 2009;18:148158.

190. Kripke DF, Garfinkel L, Wingard DL, Klauber MR, Marler MR. Mortality associated with sleep duration and insomnia. Arch Gen Psychiatry 2002;59:131-136.

191. Patel SR, Malhotra A, Gottlieb DJ, White DP, Hu FB. Correlates of long sleep duration. Sleep 2006;29:881-889.

192. Ferrie JE, Shipley MJ, Cappuccio FP, Brunner E, Miller MA, Kumari $\mathrm{M}$, et al. A prospective study of change in sleep duration: associations with mortality in the Whitehall II cohort. Sleep 2007;30:1659-1666.

193. Taheri S, Lin L, Austin D, Young T, Mignot E. Short sleep duration is associated with reduced leptin, elevated ghrelin, and increased body mass index. PLoS Med 2004;1:e62.

194. Knutson KL, Spiegel K, Penev P, Van Cauter E. The metabolic consequences of sleep deprivation. Sleep Med Rev 2007;11:163178.

195. Schmid SM, Hallschmid M, Jauch-Chara K, Wilms B, Bene$\operatorname{dict} C$, Lehnert $H_{\text {, et }}$ al. Short-term sleep loss decreases physical activity under free-living conditions but does not increase food intake under time-deprived laboratory conditions in healthy men. Am J Clin Nutr 2009;90:1476-1482.

196. Vaara J, Kyröläinen $H_{1}$ Koivu M, Tulppo M, Finni T. The effect 
of 60-h sleep deprivation on cardiovascular regulation and body temperature. Eur J Appl Physiol 2009;105:439-444.

197. Phua CS, Jayaram L, Wijeratne T. Relationship between sleep duration and risk factors for stroke. Front Neurol 2017;8:392.

198. González-Ortiz M, Martínez-Abundis E, Balcázar-Muñoz BR, Pascoe-González S. Effect of sleep deprivation on insulin sensitivity and cortisol concentration in healthy subjects. Diabetes Nutr Metab 2000;13:80-83.

199. Covassin N, Bukartyk J, Sahakyan K, Svatikova A, Calvin A, St Louis EK, et al. Experimental sleep restriction increases nocturnal blood pressure and attenuates blood pressure dipping in healthy individuals. J Am Coll Cardiol 2015;65(10 Suppl):A1352.

200. Knutson KL, Van Cauter E, Rathouz PJ, Yan LL, Hulley SB, Liu K, et al. Association between sleep and blood pressure in midlife: the CARDIA sleep study. Arch Intern Med 2009;169:1055-1061.

201. Kim JY, Yadav D, Ahn SV, Koh SB, Park JT, Yoon J, et al. A prospective study of total sleep duration and incident metabolic syndrome: the ARIRANG study. Sleep Med 2015;16:1511-1515.

202. Zhan $Y$, Chen $R, Y u$ J. Sleep duration and abnormal serum lipids: the China Health and Nutrition Survey. Sleep Med 2014;15:833-839.

203. Meier-Ewert HK, Ridker PM, Rifai N, Regan MM, Price NJ, Dinges DF, et al. Effect of sleep loss on C-reactive protein, an inflammatory marker of cardiovascular risk. J Am Coll Cardiol 2004;43:678-683.

204. Shearer WT, Reuben JM, Mullington JM, Price NJ, Lee BN, Smith EO, et al. Soluble TNF-alpha receptor 1 and IL-6 plasma levels in humans subjected to the sleep deprivation model of spaceflight. J Allergy Clin Immunol 2001;107:165-170.

205. Prather AA, Vogelzangs N, Penninx BW. Sleep duration, insomnia, and markers of systemic inflammation: results from the Netherlands Study of Depression and Anxiety (NESDA). J Psychiatr Res 2015;60:95-102.

206. Abe T, Aoki T, Yata S, Okada M. Sleep duration is significantly associated with carotid artery atherosclerosis incidence in a Japanese population. Atherosclerosis 2011;217:509-513.

207. Khawaja O, Sarwar A, Albert CM, Gaziano JM, Djoussé L. Sleep duration and risk of atrial fibrillation (from the Physicians' Health Study). Am J Cardio/ 2013;111:547-551.

208. Wolf PA, Abbott RD, Kannel WB. Atrial fibrillation as an independent risk factor for stroke: the Framingham Study. Stroke 1991;22:983-988.

209. Ramos AR, Dong C, Rundek T, Elkind MS, Boden-Albala B, Sacco $R L$, et al. Sleep duration is associated with white matter hyperintensity volume in older adults: the Northern Manhattan Study. J Sleep Res 2014;23:524-530.

210. Ramos AR, Gangwisch JE. Is sleep duration a risk factor for stroke? Neurology 2015;84:1066-1067.
211. Knutson $\mathrm{KL}$, Turek FW. The U-shaped association between sleep and health: the 2 peaks do not mean the same thing. Sleep 2006;29:878-879.

212. Grandner MA, Drummond SP. Who are the long sleepers? Towards an understanding of the mortality relationship. Sleep Med Rev 2007;11:341-360.

213. Hwangbo Y, Kim WJ, Chu MK, Yun CH, Yang KI. Association between weekend catch-up sleep duration and hypertension in Korean adults. Sleep Med 2013;14:549-554.

214. Im HJ, Baek SH, Chu MK, Yang KI, Kim WJ, Park SH, et al. Association between weekend catch-up sleep and lower body mass: population-based study. Sleep 2017;40:zsx089.

215. Buysse DJ. Insomnia. JAMA 2013;309:706-716.

216. American Academy of Sleep Medicine. The International Classification of Sleep Disorders. 3rd ed. Darien, IL: American Academy of Sleep Medicine, 2014.

217. Chien KL, Chen PC, Hsu HC, Su TC, Sung FC, Chen MF, et al. Habitual sleep duration and insomnia and the risk of cardiovascular events and all-cause death: report from a community-based cohort. Sleep 2010;33:177-184.

218. Bonnet $\mathrm{MH}$, Arand DL. Cardiovascular implications of poor sleep. Sleep Med Clin 2007;2:529-538.

219. Phillips B, Mannino DM. Do insomnia complaints cause hypertension or cardiovascular disease? J Clin Sleep Med 2007;3:489-494.

220. Vgontzas AN, Liao D, Bixler EO, Chrousos GP, Vela-Bueno A. Insomnia with objective short sleep duration is associated with a high risk for hypertension. Sleep 2009;32:491-497.

221. Fernandez-Mendoza J, Calhoun S, Bixler EO, Pejovic S, Karataraki $\mathrm{M}$, Liao $\mathrm{D}$, et al. Insomnia with objective short sleep duration is associated with deficits in neuropsychological performance: a general population study. Sleep 2010;33:459-465.

222. Fernandez-Mendoza J, Vgontzas AN, Liao D, Shaffer ML, Vela-Bueno A, Basta $M$, et al. Insomnia with objective short sleep duration and incident hypertension: the Penn State Cohort. Hypertension 2012;60:929-935.

223. Scofield $H$, Roth T, Drake C. Periodic limb movements during sleep: population prevalence, clinical correlates, and racial differences. Sleep 2008;31:1221-1227.

224. Hornyak M, Feige B, Riemann D, Voderholzer U. Periodic leg movements in sleep and periodic limb movement disorder: prevalence, clinical significance and treatment. Sleep Med Rev 2006;10:169-177.

225. Kendzerska T, Gershon AS, Hawker G, Leung RS, Tomlinson G. Obstructive sleep apnea and risk of cardiovascular events and all-cause mortality: a decade-long historical cohort study. PLoS Med 2014;11:e1001599.

226. Mirza M, Shen WK, Sofi A, Jahangir A, Mori N, Tajik AJ, et al. 
Frequent periodic leg movement during sleep is associated with left ventricular hypertrophy and adverse cardiovascular outcomes. J Am Soc Echocardiogr 2013;26:783-790.

227. Walters AS, Rye DB. Review of the relationship of restless legs syndrome and periodic limb movements in sleep to hypertension, heart disease, and stroke. Sleep 2009;32:589-597.

228. Pennestri MH, Montplaisir J, Colombo R, Lavigne G, Lanfranchi PA. Nocturnal blood pressure changes in patients with restless legs syndrome. Neurology 2007;68:1213-1218.

229. Allen RP, Picchietti DL, Garcia-Borreguero D, Ondo WG, Walters AS, Winkelman JW, et al. Restless legs syndrome/WillisEkbom disease diagnostic criteria: updated International Restless Legs Syndrome Study Group (IRLSSG) consensus criteria. History, rationale, description, and significance. Sleep Med 2014;15:860-873.

230. Winkelman JW, Shahar E, Sharief I, Gottlieb DJ. Association of restless legs syndrome and cardiovascular disease in the Sleep Heart Health Study. Neurology 2008;70:35-42.

231. Elwood P, Hack M, Pickering J, Hughes J, Gallacher J. Sleep disturbance, stroke, and heart disease events: evidence from the Caerphilly cohort. J Epidemiol Community Health 2006;60:6973.

232. Molnar MZ, Lu JL, Kalantar-Zadeh K, Kovesdy CP. Association of incident restless legs syndrome with outcomes in a large cohort of US veterans. J Sleep Res 2016;25:47-56.

233. Szentkirályi A, Völzke $H$, Hoffmann W, Happe S, Berger K. A time sequence analysis of the relationship between cardiovascular risk factors, vascular diseases and restless legs syndrome in the general population. J Sleep Res 2013;22:434-442.

234. Winter AC, Berger K, Glynn RJ, Buring JE, Gaziano JM, Schürks $M$, et al. Vascular risk factors, cardiovascular disease, and restless legs syndrome in men. Am J Med 2013;126:228-235.

235. Li Y, Li Y, Winkelman JW, Walters AS, Han J, Hu FB, et al. Pro- spective study of restless legs syndrome and total and cardiovascular mortality among women. Neurology 2018;90:e135e141.

236. Li Y, Wang W, Winkelman JW, Malhotra A, Ma J, Gao X. Prospective study of restless legs syndrome and mortality among men. Neurology 2013;81:52-59.

237. Winkelman JW, Finn L, Young T. Prevalence and correlates of restless legs syndrome symptoms in the Wisconsin Sleep Cohort. Sleep Med 2006;7:545-552.

238. Schilling C, Schredl M, Strobl P, Deuschle M. Restless legs syndrome: evidence for nocturnal hypothalamic-pituitaryadrenal system activation. Mov Disord 2010;25:1047-1052.

239. May AM, Blackwell T, Stone KL, Cawthon PM, Sauer WH, Varosy $P D$, et al. Longitudinal relationships of periodic limb movements during sleep and incident atrial fibrillation. Sleep Med 2016;25:78-86.

240. Hannerz H, Albertsen $K$, Nielsen ML, Tuchsen F, Burr H. Occupational factors and 5 -year weight change among men in a danish national cohort. Health Psychol 2004;23:283-288.

241. Kawachi I, Colditz GA, Stampfer MJ, Willett WC, Manson JE,

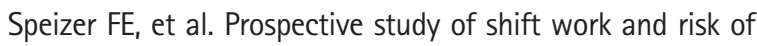
coronary heart disease in women. Circulation 1995;92:31783182.

242. Suwazono Y, Dochi M, Oishi M, Tanaka K, Kobayashi E, Sakata K. Shiftwork and impaired glucose metabolism: a 14-year cohort study on 7104 male workers. Chronobiol Int 2009;26:926941.

243. Suwazono Y, Dochi M, Sakata K, Okubo Y, Oishi M, Tanaka K, et al. A longitudinal study on the effect of shift work on weight gain in male Japanese workers. Obesity (Silver Spring) 2008;16:1887-1893.

244. Kecklund G, Axelsson J. Health consequences of shift work and insufficient sleep. BMJ 2016;355:i5210. 